\title{
Review Article \\ Trends and Advances in Separation and Detection of SSRIs and SNRIs in Biological Matrices
}

\author{
Ruchita Das and Y. K. Agrawal \\ Institute of Research and Development, Gujarat Forensic Sciences University, Sector 18/A, Gandhinagar, Gujarat 382007, India \\ Correspondence should be addressed to Ruchita Das; das_ruchita@yahoo.com
}

Received 5 March 2013; Accepted 19 May 2013

Academic Editor: Toyohide Takeuchi

Copyright ( 2013 R. Das and Y. K. Agrawal. This is an open access article distributed under the Creative Commons Attribution License, which permits unrestricted use, distribution, and reproduction in any medium, provided the original work is properly cited.

Nowadays antidepressant drugs like selective serotonin reuptake inhibitors (SSRIs) and selective norepinephrine reuptake inhibitors (SNRIs) represent the first choice in the treatment of moderate to severe depressive illness, various phobias, and personality disorders. In spite of the therapeutic aspects, they often produce very severe and toxic effects in deliberate and accidental cases of poisoning. These are also considered as date-rape drugs used for drugged victims for raping or robbing. Therefore, in recent years, their analyses in different biological matrices for clinical and toxicological analysis purposes has been a target worthy of interest. Thus, the review focuses on recent advancements of various separation techniques like chromatography and electrophoresis that are concernd with the determination of selective serotonin reuptake inhibitor and selective norepinephrine reuptake inhibitor drugs and their metabolites in various biological matrices. In addition to this, a critical discussion on analytical approaches has also been incorporated, suggesting their applicability and limitations for further implementations. Thus, this paper will definitely help in the selection and development of proper analytical methodologies to achieve satisfactory results, better scientific understanding, and test interpretation.

\section{Introduction}

Depression is a common and widespread mental disorder affecting millions of people worldwide [1]. It often leads to severe, chronic, and life-threatening illness, affecting the economic and social behaviour of an individual drastically $[2,3]$. Even more than $20 \%$ of the adult population of the world suffers from depression which may lead to suicidal behaviour [3, 4]. To control such psychic conditions, antidepressant drugs are administered which usually produce effects by blocking the neuronal uptake of biogenic amines $[5,6]$. Antidepressants are characterized as 1st, 2nd, and 3rd or the so-called new generation, depending on when they were developed [1]. The new generation antidepressant drugs are the most widespread class of drug and are in fact becoming the drugs of first choice for the treatment of depression, because they are considered to be more potent than other antidepressant groups $[5,7]$. The highly prescribed classes of this category are selective serotonin reuptake inhibitors (SSRIs) (fluoxetine (FLX), citalopram (CIT), paroxetine (PAR), sertraline
(SER), and fluvoxamine (FLV)) and selective norepinephrine reuptake inhibitors (SNRIs) (venlafaxine (VLF), milnacipran (MCP), and duloxetine (DLX)) (Figure 1) [8]. However, these drugs are created with improved margin of safety but need monitoring due to their side effects and rapid abusiveness, because they are likely to produce mental alertness that increases physical activities [9-12]. Cases were also observed in which suicidal and accidental deaths occurred involving antidepressant drugs that are frequently abused, creating a topic of interest in forensic chemistry and toxicology [13-15]. In addition to this, they were also considered as date-rape drugs, used for the purpose of drugging unsuspected victims for raping or robbing [16].

Thus, the aim of this paper is to provide a systematic survey of various chromatographic and electrophoretic techniques used for the analysis of SSRIs, SNRIs, and their corresponding metabolites in various biological matrices. These assays consist of three components as the types of biological samples, their pretreatments or isolation, and the techniques of detection and quantitation. All of them 
influence the accuracy, precision, selectivity, and sensitivity of the analytical methods used. This will simplify the rapid selection of a suitable method for satisfactory clinical and toxicological analyses. To the best of our knowledge, such a review has not yet appeared.

\section{Separation Techniques Used for the Detection of SSRIs, SNRIs, and Their Metabolites}

The separation of analyte of interest forms two basic approaches, the first one is the sample preparation step and the second is the detection of the compound of interest. A number of extraction techniques have been routinely used for the removal of as many as interfering compounds and preconcentration of the analytes. A variety of methods have been published or validated in order to determine the amount of antidepressants in different biological matrices which can fabricate a broad investigating area in the field of therapeutics as well as forensics. These methods offer good precision and accuracy over the entire analytical range, allowing the development of very rapid and efficient methods. Thus, in the next subsections discussion about various analytical methods and sample pretreatment techniques have been incorporated and tabulated.

2.1. Liquid Chromatography (LC). LC provides a wide range of linearity with many detectors as fluorescence detector (FD) [17], ultraviolet-visible (UV-Vis) detector [18], and MS detector [19], maximumly in combination of $\mathrm{C}_{18}$ column with varying ratios of mobile phases.

2.1.1. Mass Detector. LC coupled with single-stage (LCMS) or tandem mass spectrometry (TMS or LC-MS-MS) is becoming increasingly important in routine laboratory analysis of antidepressant drugs especially from whole blood, plasma/serum, and urine. The alternative matrices such as hair and oral fluid have also given satisfactory results [20]. Moreover, MS has been the most commonly used detector in the determination of antidepressants, the high specificity and the lower limits of detection obtained being the main advantages with this detection technique. With a mass spectrometer, it is possible to monitor only the mass of the analyte which is extremely beneficial in the structural elucidation studies. A precise, sensitive, and high throughput LC-TMS method was developed for simultaneous determination of SER and its primary metabolite, Ndesmethylsertraline (DSER) in human plasma. The analytes were extracted from plasma via liquid-liquid extraction (LLE) in methyl tert-butyl ether. The chromatographic conditions were aimed for getting an adequate response, a sharp peak shape, and a short run time per analysis. It was observed that $1 \mathrm{M}(2.5 \mathrm{~mL})$ ammonium trifluoroacetate in $750 \mathrm{~mL}$ methanol $+250 \mathrm{~mL}$ deionized water as the mobile phase provides faster elution, better efficiency, and a peak shape. The use of Betasil $\mathrm{C}_{8}$ chromatographic column helped in the separation and elution of both compounds in a very short time of 1.40 and $1.47 \mathrm{~min}$ for SER and N-DSER, respectively. The maximum on-column loading per sample injection was $0.45 \mathrm{ng}$ for both analytes [21]. This volume was considerably less as compared to other reported procedures (injection volume of $20 \mu \mathrm{L}$ ), but the former method helped in maintaining the efficiency and lifetime of the column which in turn gives consistent and reproducible recoveries of analytes [22].

Quantitative estimations of VLF and desmethylvenlafaxine (DVLF) were carried out in biological samples obtained from postmortem cases. VLF and one of its active metabolites, DVLF, were identified by LC-MS using atmospheric pressure ionisation (API) electrospray in positive mode, followed by extraction through $n$-butyl chloride. Chromatographic separation was performed on $\mathrm{C}_{18}$ column and the mobile phase consisted of ammonia $(0.05 \mathrm{M}$ / methanol/tetrahydrofuran (32.5:67.0:0.5 vol\%)) titrated to $\mathrm{pH}=10.0$ with $12 \mathrm{M}$ formic acid and achieved retention time of 9.1 and $3.5 \mathrm{~min}$ for VLF and DVLF, respectively. Moreover, the postmortem tissue concentrations observed were $0.1-36$ and $<0.05-3.5 \mathrm{mg} / \mathrm{L}$ (peripheral blood), $<0.05-$ 22 and $<0.05-9.9 \mathrm{mg} / \mathrm{kg}$ (liver), and $<0.05-10$ and $<0.05-$ $1.5 \mathrm{mg} / \mathrm{L}$ (vitreous), $<0.05-55$ and $<0.05-21 \mathrm{mg} / \mathrm{L}$ (urine), respectively. Additionally, it was also reported that VLF alone was not responsible for intoxication in the above described postmortem studies. However, it has shown synergism in presence of other drugs like FLX and moclobemide, which could be liable for fatality [23]. An atmospheric pressure chemical ionization tandem mass spectrometry (APCI-MS/MS) method was developed for the identification and quantitation of CIT, FLV, and PAR in human plasma. Direct analysis of plasma samples was done after dilution in $0.1 \%$ formic acid, followed by direct injection into the HPLC system, avoiding a time-consuming sample preparation step. Proteins and other large biomolecules were removed during an online sample cleanup step. The limit of quantitation (LOQ) obtained was below $20 \mathrm{ng} / \mathrm{mL}$ which permitted the direct analysis of plasma samples [24].

The method of sample introduction to the ionisation source is very important while using a mass detector, and it often depends on the ionisation method being used. The ionisation method to be used should depend on the type of sample under investigation. Different types of ionisation sources were used for quantification of SSRIs and SNRIs. Electron spray ionisation (ESI) mode, in combination with LC, was used for quantification of FLX in plasma samples $[25,26]$. As compared to the above electron spray ionisation (ESI) method, APCI mode has also provided higher mass spectrometric response and less susceptibility to ion suppression [27].

Fully automated online solid phase extraction (SPE) coupled to LC-TMS was developed and validated for direct analysis of 14 antidepressants including SSRIs and their metabolites in plasma. The integration of sample extraction and HPLC separation into a single system permitted direct injection of the plasma without prior sample pretreatment. An automated online SPE-LC-MS/MS method permitted direct injection of $50 \mathrm{~mL}$ of plasma without prior sample pretreatment, ensuring the analysis of the samples in $20 \mathrm{~min}$. 
<smiles>COCCCC/C(=N\OCCN)c1ccc(C)cc1</smiles>

Fluvoxamine (FLV)<smiles>CN(C)CCCC1(c2ccc(F)cc2)OCc2cc(C#N)ccc21</smiles>

Citalopram (CIT)<smiles>Fc1ccc([C@H]2CCNC[C@H]2COc2ccc3c(c2)OCO3)cc1</smiles>

Paroxetine (PAR)<smiles>C=C/C=C(\C)[C@]1(C(=O)N(CC)CC)C[C@H]1CN</smiles>

Milnacipran (MCP)<smiles>CNCCC(Oc1ccc(C(F)(F)F)cc1)c1ccccc1</smiles>

Fluoxetine (FLX)<smiles>CN[C@H]1CC[C@@H](c2ccc(Cl)c(Cl)c2)c2ccccc21</smiles>

Sertraline (SER)<smiles>C=c1cccc/c1=C(/C)O[C@H](CCNC)c1cccs1</smiles>

Duloxetine (DLX)<smiles>COc1ccc(C(CN(C)C)C2(O)CCCCC2)cc1</smiles>

Venlafaxine (VLF)

FIGURE 1: Structures of SSRIs (FLX, CIT, PAR, SER, and FLV) and SNRIs (VLF, MCP, and DLX) group of drugs.

Several deuterated drugs were employed as internal standards. For the detection, a tandem mass spectrometer with a triple quadrupole was employed operating in electrospray in the positive ionization mode. Selectivity of the method was achieved by a combination of the retention time and two precursor-product ion transitions for the nondeuterated compounds. The LOQs were estimated as $10 \mathrm{ng} / \mathrm{mL}$ for all compounds [28].

Recently, a new kind of sample preparation media has been developed as restricted access media (RAM) and possesses a biocompatible surface and adsorption centres which provide very fine extraction in minimal amount of sampling 
(nearly $1 \mu \mathrm{L}$ ). This could be related to miniaturization of chromatographic separation, especially with the improvement of mass sensitivity. By giving minimal sample pretreatment through RAM, FLX was detected in plasma by direct analysis through LC-MS in total run time of $8 \mathrm{~min}$. Calibration curves are constructed under a linear range of 1$250 \mathrm{ng} / \mathrm{mL}$ with $\mathrm{LOQ}=1 \mathrm{ng} / \mathrm{mL}$. This demonstrates the applicability of a new capillary RAM-LC-MS/MS approach for the detection of antidepressant drugs with less consumption of time, solvent, and samples [29]. Likewise, the integration of the sample extraction apparatus with LC separation and MS detection into a single system permitted the direct injection of diluted urine or plasma samples after filtration. An automated in-tube solid-phase microextraction (SPME) LC-MS method was developed for the analysis of SSRIs and SNRIs in urine and plasma. A hybrid organic-inorganic silica monolith with cyano-ethyl functional groups was prepared and used as a sorbent for in-tube SPME. The total process time was $30 \mathrm{~min}$, and only $30 \mu \mathrm{L}$ of urine or plasma was required in one analysis cycle, achieving good extraction efficiencies and recoveries (urine and plasma were from $75.2 \%$ to $113.0 \%$ ) with no matrix interferences. Limit of detection (LOD) was found as $0.06-2.84 \mathrm{ng} / \mathrm{mL}$ in urine and $0.07-2.95 \mathrm{ng} / \mathrm{mL}$ in plasma. This could minimize repetitive work and also eliminates the analyst's exposure to hazardous and toxic solvents [30].

A new type of polymer column (Shim-pack MAYI-ODS) has been used for the separation of SER, FLV, and PAR in human serum by LC-MS/MS. This column is having a unique online dilution by pass channel which can reduce labour and enhances efficiency. The recoveries of the three drugs in human serum were observed as $29.2 \%-45.7 \%$ at $20 \mathrm{ng} / \mathrm{mL}$ and $52.0 \%-53.7 \%$ at $80 \mathrm{ng} / \mathrm{mL}$ of injection, and each drug had a detection limit of $1-3 \mathrm{ng} / \mathrm{mL}$. Thus, the method enabled direct injection of crude biological samples without complicated pretreatments and without column switching system [31].

CIT and its metabolites desmethylcitalopram (DCIT) and didesmethylcitalopram (DDCIT) were separated from plasma samples through SPE, using two types of cartridges during extraction, $\mathrm{C}_{8}$ and Oasis hydrophilic-lipophilic balance cartridges. $\mathrm{C}_{8}$ cartridge has produced good extraction yields, but some interference was also detected due to plasma matrix, while the results obtained with Oasis hydrophiliclipophilic balance cartridges were better in terms of extraction yield and selectivity. Thus, the later procedure was chosen for extraction, achieving LOQ $=1.5 \mathrm{ng} / \mathrm{mL}$ for CIT and DCIT and $2.0 \mathrm{ng} / \mathrm{mL}$ for DDCIT [32]. CIT and DCIT were also quantified from neonatal hair samples which suggest gestational exposure of these drugs. A LC-TMS method has been developed and validated for the assay of CIT in neonatal hair samples which also explores the utility of alternative test matrices in detection [33].

On the contrary, a simple chemical treatment to the biological sample can also allow the direct injection of the supernatant to the column. A very sensitive HPLC-TMS with ESI method was developed for the simultaneous determination of FLX and norfluoxetine (NFLX) in human plasma. It was observed that the addition of formic acid to mobile phase could improve sensitivity by promoting the ionization of analytes. Acetonitrile was found to be more favourable for the chromatographic separation of FLX and NFLX from matrix than methanol and able to produce high sensitivity (retention time $=3.8 \mathrm{~min}$ ), lowest background noise, and most stable MS signals (Figures 2(a) and 2(b)) [34].

Except for all these proposed methods, a very noble HPLC-TMS method (with single sample/triple injection approach) was developed and validated for the simultaneous determination of forty-eight antidepressants (including SSRIs and SNRIs), antipsychotics, and their pharmacologically active metabolites in serum. The chromatographic separation was performed on a monolithic $\mathrm{C}_{18}$ column $(50 \mathrm{~mm} \times$ $4.6 \mathrm{~mm}$ ) with methanol gradient and $5 \mathrm{mM}$ acetate buffer ( $\mathrm{pH}$ 3.9). The sample volume needed for analysis was very less $(0.1 \mathrm{~mL})$ which requires only protein precipitation and stepwise dilution for sample preparation. After ESI, positive ion fragments were detected in the multiple reaction monitoring mode. The LOQ was found as 1.0, 2.17, 1.17, 1.07, $0.70 \mathrm{ng} / \mathrm{mL}$ for CIT, FLX, FLV, PAR, and SER, respectively. The advantage of the method was to minimize the expenditure for routine determination of large set of individuals with varying drug combinations [35].

Newer techniques like ultra-high performance liquid chromatography (UHPLC) have managed to reduce the time analysis and the effectiveness of the separations. An UHPLC-time-of-flight (UHPLC-TOF-MS) method has been proposed for the simultaneous screening and quantification of 52 drugs, including SSRIs in 15 autopsy hair samples, with a total chromatographic run time of $17 \mathrm{~min}$. Hair samples were liquid-liquid extracted with methanol, acetonitrile, ammonium formate $(2 \mathrm{mM}, 8 \%$ acetonitrile, $\mathrm{pH}$ and 5.3) overnight at $37^{\circ} \mathrm{C}$. The LODs for CIT, FLX, and VLF were found to be $0.01 \mathrm{ng} / \mathrm{mL}$, and for SER and PAR they were found to be 0.02 and $0.05 \mathrm{ng} / \mathrm{mL}$, respectively [36]. Likewise, HPLC-HRMS (high resolution mass spectroscopy) method for simultaneous screening and quantification of 28 drugs, including VLF and FLX, was developed and validated on hair samples. The samples $(2.5 \mathrm{mg})$ were extracted with $200 \mu \mathrm{L}$ of a mixture of water: acetonitrile: $1 \mathrm{M}$ trifluoroacetic acid $(80: 10: 10, \mathrm{v} / \mathrm{v})$. Total chromatographic run time was $26 \mathrm{~min}(\mathrm{VLF}=16.3 \mathrm{~min}$ and FLX $=20.5 \mathrm{~min})$, reaching lower limit of quantitation (LLOQs) as low as $0.1-0.5 \mathrm{ng} / \mathrm{mg}$, which are particularly suitable for the forensic determination of selected antidepressants [37].

2.1.2. UV Detector. Owing to the wide applicability of the UV detector, it has been deemed suitable for the development of multiresidue liquid chromatography methods [38]. In order to achieve good chromatographic separation and enhancement of signals, different types of extraction procedures were adopted for the removal of interfering particles such as LLE, SPE, stir bar sorptive extraction (SBSE), and liquid-phase microextraction (LPME) which has given a detection limit up to nano or pico level [39]. Sometimes for multicomponent analysis [40] dual UV wavelength detection [41] has also been used for the identification of compounds. An isocratic reverse phase HPLC (RP-HPLC) method with UV detection was optimised for the determination of SER, FLV, FLX, PAR, CIT, 

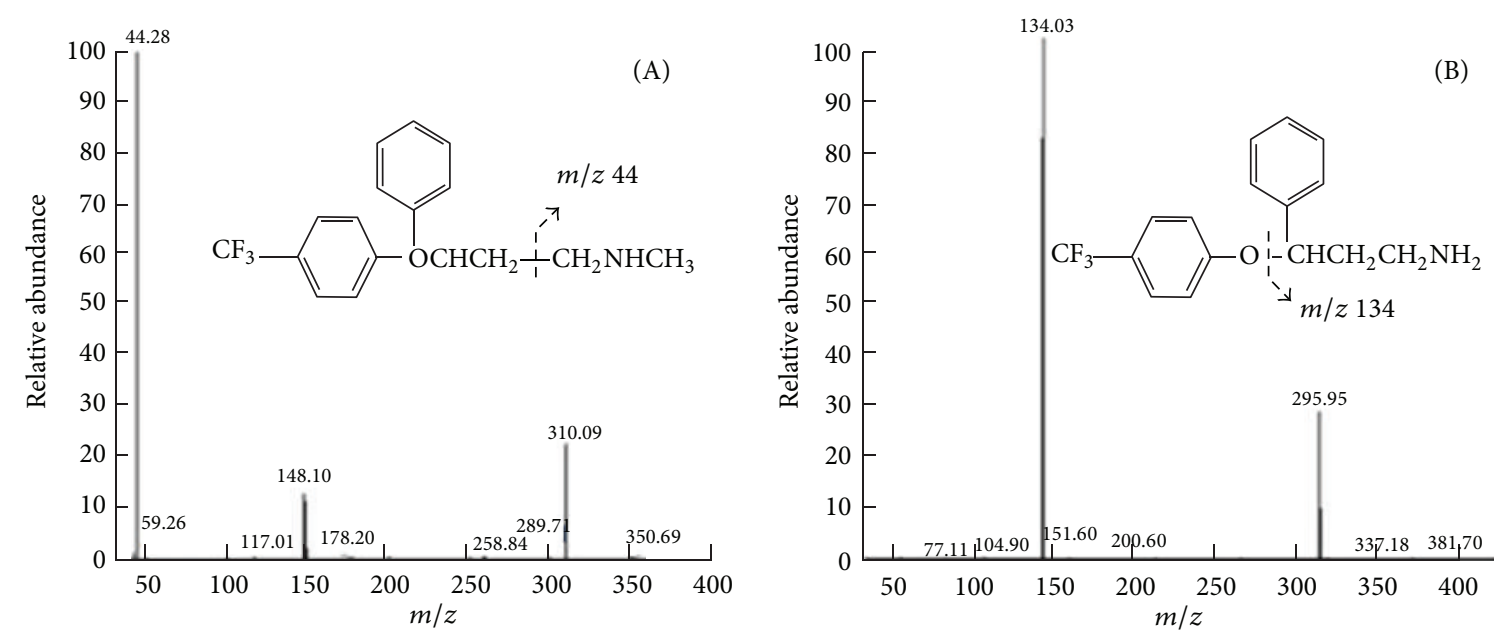

(a)
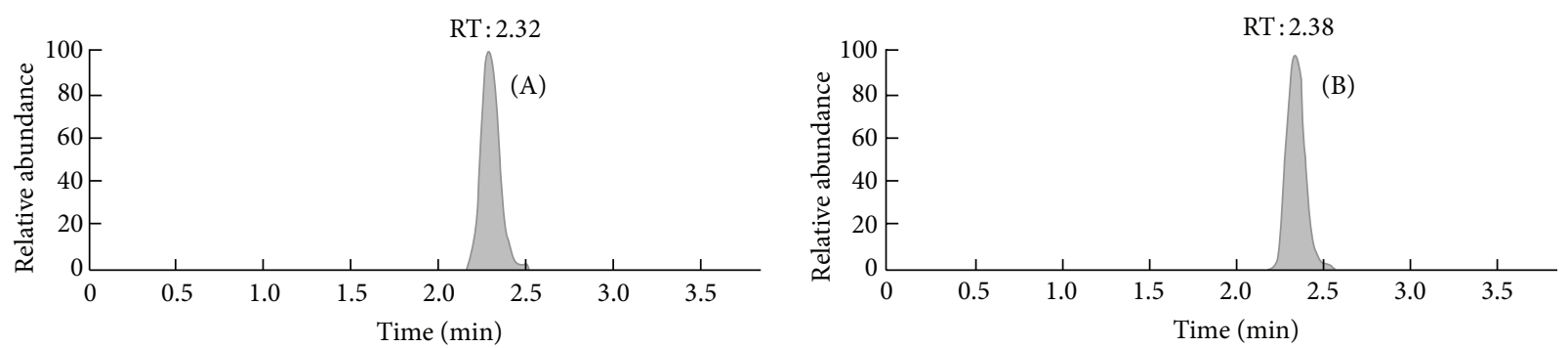

(b)

Figure 2: (a) The product ion spectra of $[\mathrm{M}+\mathrm{H}]^{+}$of (A) Fluoxetine and (B) Norfluoxetine. (b) Chromatogram of plasma sample spiked with (A) Fluoxetine $(3.0 \mathrm{ng} / \mathrm{mL}$ ) and (B) Norfluoxetine $(2.6 \mathrm{ng} / \mathrm{mL})$ (reproduced with the permission from [34]).

MCP, VLF, and o-desmethylvenlafaxine (ODV) in human serum. The SPE, yielded reproducible recoveries from 75 to $99 \%$, allowed efficient and rapid analysis in minimum amount of time [42].

Recently, a newer kind of hollow fibre based liquidphase microextraction (HF-LPME) was evaluated for the extraction and preconcentration of SER from urine and plasma samples prior to its determination by HPLC-UV. This is a kind of miniaturised isolation technique based on the use of disposable, porous, hollow fibres made of polypropylene, which can combine extraction, concentration, and sample cleanup in one step only. The calibration curves were obtained in the range of $5-500 \mu \mathrm{g} / \mathrm{L}$ with reasonable linearity $\left(R^{2}>0.998\right)$. Hence, the method indicates the applicability of hollow fibre microextraction as an excellent cleanup procedure and can be served as a simple and sensitive method for monitoring antidepressant drugs in the biological samples [18].

Consequently, there has been an increased effort to develop standardized methods for quantifying psychotropic medications in breast milk which also shows the in utero exposure of these drugs. A method was developed on HPLCUV for measuring antidepressants in human breast milk. The extraction of drugs was achieved by both techniques as LLE and SPE. Three kinds of assays were performed during analysis, in which assay 1 measured FLX, NFLX, and FLV; assay 2 measured SER and DSER; and assay 3 measured the tricyclic antidepressants. This method was found as highly accurate and precise in measuring the selected antidepressants in human breast milk as it was free from matrix effects which were often encountered in breast milk drug analysis [43].

In HPLC analysis, thermal desorption at high temperature creates practical problems such as degradation of the polymer, and furthermore, many nonvolatile compounds cannot be completely desorbed from a fiber. Solvent desorption is thus proposed as an alternative method for SPMEHPLC coupling. An organic solvent (static desorption) or the mobile phase (dynamic desorption) is used to desorb the analytes from the SPME fiber. A high throughput SPMEHPLC-UV method has been developed with high sensitivity, precision, and accuracy and enabled the quantification of CIT, SER, PAR, DLX, and FLX in human plasma, following oral administration. For the extraction of $250 \mathrm{~mL}$ of plasma, $4 \mathrm{~mL}$ of phosphate buffer ( $\mathrm{pH} 7$ ) was added, and the extraction was carried out at $25^{\circ} \mathrm{C}$ for $40 \mathrm{~min}$, using a modified fibre obtained by the electrochemical deposition (cyclic voltammetry) of a polypyrrole (PPY) film on a stainless steel wire. The drug liquid desorption was made on mobile phase at $25^{\circ} \mathrm{C}$ for $15 \mathrm{~min}$. The LOD was found $20 \mathrm{ng} / \mathrm{mL}$ for CIT 


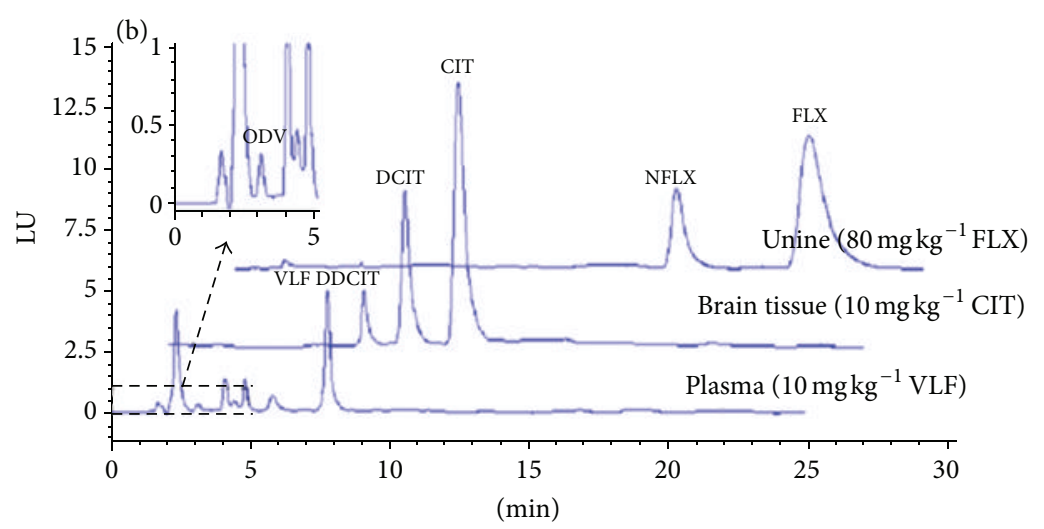

FIGURE 3: Chromatograms obtained from plasma and brain tissue of rat and urine of human.

and PAR and $25 \mathrm{ng} / \mathrm{mL}$ for FLX and SER, while $16 \mathrm{ng} / \mathrm{mL}$ for DLX [44].

At times, a fully automated procedure was also used and allowed online extraction of the drug by HPLC. CIT and its S-enantiomer escitalopram (EsCIT) were quantitatively determined from serum by column-switching HPLC in combination with UV and obtained LOD $=6 \mathrm{ng} / \mathrm{mL}$. The method was found to be sensitive and time and solvent saving [45]. A highly selective HPLC method has been developed to detect secondary amine-bearing antidepressants (PAR and FLX) and their metabolites by using 7,7,8,8 tetracyanoquinodimethane (TCNQ) as a derivatizing agent in plasma samples. The method was based on purple chromogens formed by the displacement reaction of the drugs with a derivatizing agent. The resulting chromogens were directly separated by RP-HPLC. For chromatographic separation, $\mathrm{C}_{18}$ column was used in combination with acetonitrile-water $(60: 40)$ as the mobile phase and achieved complete separation in $40 \mathrm{~min}$. The LOD observation varied mostly between 240 and $480 \mathrm{ng} / \mathrm{mL}$ [46].

2.1.3. Fluorescence Detector. It has also been observed that the fluorescence detection has some advantages over ultraviolet detection. In addition to higher sensitivity, FD is more specific and selective in reducing some interfering peaks. It was the first detection method used for the analysis of CIT and its DCIT. This method required the LLE extraction of the analytes with hexane from alkaline plasma and their derivatization with 9,10-dimethoxyanthracene-2-sulfonate [47]. Similar detection technique has been applied for the detection of CIT and its metabolites in plasma samples with a successive column-switching technique. Plasma samples were injected directly onto a guard column where the analytes were retained and later eluted, employing a six-port valve by the backflush method. The compounds were analyzed at an excitation wavelength of 249 and an emission wavelength of $302 \mathrm{~nm}$ [48].

SBSE, coupled with HPLC-FD, was used for the quantification of FLX, CIT, and VLF and their active metabolites NFLX, DCIT, DDCIT, and O-DVLF in plasma, urine, and brain tissue samples. For each matrix, the analytical method has been assessed by studying the linearity and the intra- and interday accuracy (89-113\%) and precision (RSD < 13\%). In addition to this, the improvement in quantification limits was observed which made it as an applicable procedure for all the matrices useful during the forensic analysis. The use of SBSE favours improvement in the LOQ, as the surface of extraction is higher than microextraction fibers (Figure 3) [49].

The retention time of the compounds was Fluoxetine $($ FLX $)=21.2 \mathrm{~min}$ and its metabolite norfluoxetine $(\mathrm{NFLX})=$ $16.1 \mathrm{~min}$, Citalopram $(\mathrm{CIT})=10.6 \mathrm{~min}$ and its metabolites odesmethylvenlafaxine $(\mathrm{ODV})=3.1 \mathrm{~min}$, didesmethylcitalopram $(\mathrm{DDCIT})=7.0 \mathrm{~min}$, venlafaxine $(\mathrm{VLF})=7.8 \mathrm{~min}$, and desmethylcitalopram $($ DCIT $)=8.6 \mathrm{~min}$. (Reproduced with the permission from [49])

Likewise, a quantitative analysis of PAR and MCP has been achieved using an isocratic RP-HPLC combined with FD from human serum samples which reported good linearity and correlation coefficients $(r=0.999)$. Extraction was done with LLE which gave high efficiency, selectivity, and simplicity for the given method and observed less elution time for PAR (7.2 min) [50]. This is very low as compared to the above reported procedure $(15.3 \mathrm{~min})$ in spite of the use of high throughput SPE [42].

Similarly, FLX was detected in serum using 4-chloro-7nitro-2,1,3-benzofurazan as a precolumn derivatizing agent in order to improve the sensitivity of the assay. The chromatographic separation was performed on $\mathrm{C}_{18}$ column, and the fluorescence derivatives of the drugs were monitored at the excitation and emission wavelengths of 470 and $537 \mathrm{~nm}$, respectively. Achieved LOQ $(0.5 \mathrm{ng} / \mathrm{mL})$ within $6 \mathrm{~min}$, which was more satisfactory than other reported methods, which allowed the determination of low blood FLX levels also. It has been observed that the formations of derivative products were highly dependent on the $\mathrm{pH}$ of buffer solution, time, temperature, concentration of the labelling agent, and polarity of the medium. [51]. Other derivatizing agents have also been used to improve the sensitivity of the assay as 4-fluoro-7-nitrobenzofurazan [52], fluorescamine [53], and dansyl chloride [54]. However, while using fluorescamine and dansyl derivatives, there might be a possibility of poor photo stability and band broadening of the resulted peaks. Table 1 represents the LC methods in combination with various 
TABLE 1: Liquid chromatographic methods developed for detection of SSRIs, SNRIs, and their metabolites.

\begin{tabular}{|c|c|c|c|c|c|}
\hline Matrix & Analyte & Extraction method & Detector system & Sensitivity & References \\
\hline \multicolumn{6}{|c|}{ Mass detector } \\
\hline Plasma & SER and $N$-DSER & LLE & TMS & $\mathrm{LOQ}=0.5 \mathrm{ng} / \mathrm{mL}$ & {$[21]$} \\
\hline Plasma & FLX and NFLX & LLE & ESI, SIM* & $\begin{array}{l}\mathrm{LOQ}=2.5 \mu \mathrm{g} / \mathrm{mL} \text { for FLX and } 10 \mu \mathrm{g} / \mathrm{mL} \\
\text { NFLX }\end{array}$ & {$[25]$} \\
\hline Plasma & FLX & SBSE & ESI, SIM & $\begin{array}{l}\mathrm{LOQ}=30 \mathrm{pg} / \mathrm{mL} \text { (liquid desorption) and } \\
1.37 \mathrm{pg} / \mathrm{mL} \text { (thermal desorption) }\end{array}$ & {$[26]$} \\
\hline Hair & CIT, DCIT, and DDCIT & LLE & TMS & $\begin{array}{l}\mathrm{LOD}=10 \mathrm{pg} / \mathrm{mg} \\
\mathrm{LOQ}=20 \mathrm{pg} / \mathrm{mg}\end{array}$ & {$[33]$} \\
\hline Plasma & $\begin{array}{l}\text { VLF, } O \text {-DVLF, } N \text {-DVLF } \\
N, O- \\
\text { didesmethylvenlafaxine } \\
\text { (DDVLF) }\end{array}$ & LLE & MS & $\begin{array}{l}\mathrm{LOD}=0.4,0.2,0.3 \text {, and } 0.2 \mathrm{ng} / \mathrm{mL} \text { and } \\
\mathrm{LLOQ}=3.5,2.2,2.7 \text {, and } 1.9 \mathrm{ng} / \mathrm{mL} \text { for } \\
\text { VLF, } O \text {-DVLF, } N \text {-DVLF, and DDVLF, } \\
\text { respectively }\end{array}$ & {$[75]$} \\
\hline Plasma & SER & SPE & $\begin{array}{l}\text { Triple stage } \\
\text { (ESI, SRM) }\end{array}$ & $\mathrm{LOQ}=0.5 \mathrm{ng} / \mathrm{mL}$ & {$[76]$} \\
\hline $\begin{array}{l}\text { Oral fluid } \\
\text { and plasma }\end{array}$ & $\begin{array}{l}\text { FLX, NFLX PAR, SER, } \\
\text { FLV, CIT, and VLF }\end{array}$ & Automated SPE & $\begin{array}{l}\text { TMS (ESI), with } \\
\text { triple quadrupole }\end{array}$ & $\begin{array}{l}\mathrm{LOQ}=2 \mathrm{ng} / \mathrm{mL} \text { in oral fluid, } 2 \mathrm{ng} / \mathrm{mL} \text { in } \\
\text { plasma (except FLV } 10 \mathrm{ng} / \mathrm{mL} \text { and NFLX } \\
4 \mathrm{ng} / \mathrm{mL} \text { ) }\end{array}$ & {$[77]$} \\
\hline Plasma & FLX and NFLX & Automated SPE & $\begin{array}{l}\text { Triple stage } \\
\text { (ESI, SRM) }\end{array}$ & $\mathrm{LLOQ}=0.5 \mathrm{ng} / \mathrm{mL}$ & [78] \\
\hline Plasma & FLX and NFLX & $\begin{array}{l}\text { Online extraction } \\
\text { using column } \\
\text { switching }\end{array}$ & ESI, SIM & $\mathrm{LOQ}=25 \mathrm{ng} / \mathrm{mL}$ & {$[79]$} \\
\hline Plasma & VLF and $O-D V L F$ & SPE & TMS, SRM & $\begin{array}{l}\mathrm{LOQ}=3 \mathrm{ng} / \mathrm{mL} \text { for VLF, } 6 \mathrm{ng} / \mathrm{mL} \text { for } \\
\mathrm{DVLF}\end{array}$ & {$[80]$} \\
\hline Plasma & CIT & LLE & ESI, SIM & $\mathrm{LOQ}=0.50 \mathrm{ng} / \mathrm{mL}$ & {$[81]$} \\
\hline Plasma & CIT and DCIT & Deproteinization & MS (SIM) & $\mathrm{LOQ}=0.25$ to $0.5 \mathrm{ng} / \mathrm{mL}$ & {$[82]$} \\
\hline Plasma & FLV, PAR, and MCP & SPE & $\mathrm{QMS}(\mathrm{SSI})^{*}$ & $\begin{array}{l}\mathrm{LOD}=0.05 \text { to } 0.13 \mu \mathrm{g} / \mathrm{mL} \text { and } \mathrm{LOQ}= \\
0.10 \text { to } 0.20 \mu \mathrm{g} / \mathrm{mL}\end{array}$ & {$[83]$} \\
\hline Plasma & FLX and NFLX & LLE & TMS (ESI) & $\mathrm{LOQ}=0.15 \mathrm{ng} / \mathrm{mL}$ & {$[84]$} \\
\hline Plasma & FLX, CIT, PAR, and VLF & SPE & MS (ESI) & $\begin{array}{l}\mathrm{LOD}, \mathrm{FLX}=0.5, \mathrm{CIT}=0.3, \mathrm{PAR}=0.3 \\
\text { and } \mathrm{VEN}=0.1 \mathrm{ng} / \mathrm{mL}\end{array}$ & {$[85]$} \\
\hline Blood & $\begin{array}{l}\text { FLX, PAR, SER, FLV, } \\
\text { CIT, VLF, NFLX, DCIT, } \\
\text { DDCIT, and DVLF }\end{array}$ & LLE & TMS & $\begin{array}{l}\mathrm{LOD}=5-500 \mathrm{ng} / \mathrm{mL} \text { and } \mathrm{LOQ}=5 \mathrm{ng} / \mathrm{mL} \\
\mathrm{LOD}=20-2000 \mathrm{ng} / \mathrm{mL} \text { for } \mathrm{VLF} \text { and } \\
\mathrm{DVLF} \\
\mathrm{LOQ}=20 \mathrm{ng} / \mathrm{mL} \text { for VLF and DVLF }\end{array}$ & {$[86]$} \\
\hline \multicolumn{6}{|c|}{ UV detector } \\
\hline $\begin{array}{l}\text { Urine and } \\
\text { plasma }\end{array}$ & SER & HF-LPME & UV & $\begin{array}{l}\mathrm{LOD}=0.5 \mu \mathrm{g} / \mathrm{L} \\
\mathrm{LOQ}=2.3 \mu \mathrm{g} / \mathrm{L}\end{array}$ & {$[18]$} \\
\hline Plasma & CIT and DCIT & LLE & UV & $\mathrm{LOD}=5 \mathrm{ng} / \mathrm{mL}$ & {$[38]$} \\
\hline Plasma & $\begin{array}{l}\text { CIT, SER, FLX, PAR, and } \\
\text { DLX }\end{array}$ & SBSE & UV & $\begin{array}{l}\mathrm{LOD}=20 \mathrm{ng} / \mathrm{mL} \text { for CIT and PAR, } \\
25 \mathrm{ng} / \mathrm{mL} \text { for FLX and SER and } 16 \mathrm{ng} / \mathrm{mL} \\
\text { for DLX }\end{array}$ & {$[44]$} \\
\hline Plasma & FLX, SER, PAR, and CIT & LLE & UV & $\begin{array}{l}\mathrm{LOQ}=10 \mathrm{ng} / \mathrm{mL} \text { for FLX, SER, and PAR } \\
\text { and } 5 \mathrm{ng} / \mathrm{mL} \text { for CIT }\end{array}$ & [87] \\
\hline $\begin{array}{l}\text { Plasma and } \\
\text { urine }\end{array}$ & FLX, PAR, and VLF & SPE & UV & $\begin{array}{l}\mathrm{LOD}=0.2-0.6 \mathrm{ng} / \mu \mathrm{L} \text { in plasma and } \\
0.1-0.8 \mathrm{ng} / \mu \mathrm{L} \text { in urine }\end{array}$ & {$[88]$} \\
\hline Plasma & CIT, FLX, PAR & SPE & UV & $\mathrm{LOQ}=0.05$ to $0.26 \mathrm{mM}$ & [89] \\
\hline Plasma & $\begin{array}{l}\text { CIT, DCIT, DDCIT, FLV, } \\
\text { PAR, SER, } \\
\text { FLX, NFLX, VLF, and } \\
\text { O-DVLF }\end{array}$ & LLE & UV & $\begin{array}{l}\mathrm{LOQ}=25 \mathrm{ng} / \mathrm{mL}, 100 \mathrm{ng} / \mathrm{mL} \text { for } \mathrm{VLF} \text { and } \\
O-\mathrm{DVLF}\end{array}$ & {$[90]$} \\
\hline Plasma & $\begin{array}{l}R \text { - and } S \text {-CIT, } R \text { - and } \\
S \text {-DCIT, and } R \text { - and } \\
S \text {-DDCIT }\end{array}$ & LLE & UV & $\mathrm{LOD}>2 \mathrm{ng} / \mathrm{mL}$ & {$[91]$} \\
\hline
\end{tabular}


TABle 1: Continued.

\begin{tabular}{|c|c|c|c|c|c|}
\hline Matrix & Analyte & Extraction method & Detector system & Sensitivity & References \\
\hline \multicolumn{6}{|c|}{ Fluorescence detector } \\
\hline Plasma & FLX and NFLX & LLE & FD & $\mathrm{LLOD}=3 \mathrm{mg} / \mathrm{L}$ & {$[17]$} \\
\hline Plasma & SER and DSER & SPE & FD & $\mathrm{LOQ}=1.0 \mathrm{ng} / \mathrm{mL}$ and $\mathrm{LOD}=0.3 \mathrm{ng} / \mathrm{mL}$ & [22] \\
\hline Plasma & CIT, DCIT, DDCIT & SPE & FD & $\mathrm{LOQ}=1.5$ to $2 \mathrm{ng} / \mathrm{mL}$ & {$[32]$} \\
\hline $\begin{array}{l}\text { Plasma, } \\
\text { urine, and } \\
\text { brain tissue }\end{array}$ & $\begin{array}{l}\text { CIT, DCIT, DDCIT, } \\
\text { FLX, NFLX, VLF, and } \\
\text { O-DVLF }\end{array}$ & SBSE & FD & $\begin{array}{l}\mathrm{LOQ}=0.2 \text { to } 2 \mathrm{mg} / \mathrm{L} \text { in plasma, } 2 \text { to } \\
20 \mathrm{ng} / \mathrm{g} \text { in brain tissue, and } 1 \text { to } 10 \mathrm{mg} / \mathrm{L} \text { in } \\
\text { urine }\end{array}$ & {$[49]$} \\
\hline Serum & SER & LLE & FD & LOQ up to $2 \mathrm{ng} / \mathrm{mL}$ & {$[53]$} \\
\hline Plasma & $\begin{array}{l}\text { CIT, DCIT, DDCIT, } \\
\text { PAR, and PAR } \\
\text { metabolites }\end{array}$ & SPE & FD & $\mathrm{LOQ}=0.025$ to $0.12 \mathrm{mmol} / \mathrm{L}$ & {$[92]$} \\
\hline Serum & CIT, FLX, and NFLX & LLE & FD & $\mathrm{LOQ}=50 \mathrm{mg} / \mathrm{L}$ & [93] \\
\hline Plasma & FLX and NFLX & HF-LPME & FD & $\mathrm{LOQ}=5 \mathrm{ng} / \mathrm{mL}$ & [89] \\
\hline Plasma & CIT, DCIT, and DDCIT & SPE & FD & $\mathrm{LOD}=0.8 \mathrm{nmol} / \mathrm{L}$ & [94] \\
\hline \multicolumn{6}{|c|}{ Diode array detector } \\
\hline Plasma & $\begin{array}{l}\text { FLX, NFLX, SER, PAR, } \\
\text { CIT, FLV, VLF, MCP, and } \\
\text { DVLF }\end{array}$ & LLE & DAD & $\mathrm{LOD}=2.5$ to $5 \mathrm{ng} / \mathrm{mL}$ & {$[95]$} \\
\hline Urine & $\begin{array}{l}\text { CIT, DCIT, DDCIT, } \\
\text { FLX, and NFLX }\end{array}$ & SPME & DAD & $\mathrm{LOD}=0.01-0.09 \mathrm{mg} / \mathrm{L}$ & {$[96]$} \\
\hline
\end{tabular}

Abbreviations*: SIM: Single Ion Monitoring; QMS: Quadrupole Mass Spectrometry; SSI: Sonic Spray Ionisation.

detectors that appeared in the literature for the determination of SSRIs and SNRIs and their metabolites.

2.2. Gas Chromatography (GC). The use of GC with varying detectors has proved to be a powerful tool in the area of underivatized and derivatized drug analysis from biological extracts. The following are the different detectors used in combination with gas chromatography for the analysis of SSRIs and SNRIs in a biological matrix.

2.2.1. Mass Detector (MS). A method was developed based on a capillary gas chromatography with mass spectrometry detection in selected ion monitoring (SIM) mode for the analysis of CIT, FLX, DCIT, DDCIT, and NFLX in urine samples. An optimized SPE procedure was applied which provided a preconcentration factor of 10 , and no derivatization step was required [55].

In order to achieve a high degree of separation for SER, PAR, CIT, DCIT, DDCIT, and DSER in a plasma sample, reextraction was done at varying $\mathrm{pH}$, resulting in less interference from endogenous compounds. Such kinds of GC separations were performed using a cross-linked $30 \mathrm{~m}$ DB-35 ms silica capillary column, and helium $(\mathrm{He})$ was used as a carrier gas (flow rate $=1.5 \mathrm{~mL} / \mathrm{min}$ ), with a mass spectroscopic measurement in ESI mode. The simultaneous chromatographic separation was achieved after the derivatization of analytes with reagent $\mathrm{N}$-methyl-bis(trifluoroacetamide) [56]. SPME-GC has been used for the determination of SSRIs in urine samples. Fibers of $65 \mathrm{~mm}$ polydimethylsiloxanedivinylbenzene (PDMS-DVB) were used for the determination of the target SSRIs after simple in situ derivatization by acetylation of FLV, FLX, and SER. A $1.5 \mathrm{~g}$ aliquot of sodium chloride was then added to the samples. The vial was sealed with an aluminum cap and a teflon faced septum. It was then immersed in a water bath at $100^{\circ} \mathrm{C}$ and left to equilibrate for $5 \mathrm{~min}$. To perform the extraction, the SPME fiber was exposed to the magnetically stirred sample for $30 \mathrm{~min}$. The fiber was then immediately inserted into GC injection port and analysis was performed. Desorption time was set at $3 \mathrm{~min}$. The time required for SPME step and for GC analysis (30 min each) enabled high throughputness [57].

Derivatization is an important process which helps in large-scale screening of varieties of drug. This helps in the conversion of thermally labile and nonvolatile analytes to a suitable form for GC analysis, which has extended its use in the detection of antidepressant drugs and their metabolites. The separation of VLF, FLV, FLX, and CIT in blood samples was obtained by GC-MS operating in select ion monitoring (SIM) mode. Analytes were isolated by high yield LLE followed by derivatization through tertbutyldimethylsilylation (MTBSTFA) and tri-methylsilylation (MSTFA) reagents. Thus, the analytes were analysed in tert-butyldimethylsilylated (TBDMS) and tri-methylsilylated forms (TMS) by GC-MS. Due to superior derivatization power and intensive derivatives, silylation was believed to have the best properties for large-scale screening with a variety of substances having structural differences. The method is feasible for highly sensitive, reliable, and routinely performed 
TABLE 2: Gas chromatographic methods developed on for detection of SSRIs, SNRIs, and their metabolites.

\begin{tabular}{|c|c|c|c|c|c|}
\hline Matrix & Analyte & $\begin{array}{l}\text { Extraction } \\
\text { method }\end{array}$ & Detector system & Sensitivity & References \\
\hline \multicolumn{6}{|c|}{ Mass detector } \\
\hline Urine & FLX, VLF, SER, and CIT & SPE & EI-MS & $\begin{array}{l}\text { LOD, } 2,0.02,1.25 \text {, and } 10 \mu \mathrm{g} / \mathrm{mL} \text { for } \\
\text { FLX, VLF, SER, and CIT }\end{array}$ & {$[16]$} \\
\hline Plasma & $\begin{array}{l}\text { CIT, DCIT, DDCIT, } \\
\text { FLX, and NFLX }\end{array}$ & SPE & MS & $\mathrm{LOD}=0.7$ to $33.6 \mu \mathrm{g} / \mathrm{mL}$ & {$[55]$} \\
\hline Plasma & $\begin{array}{l}\text { CIT, DCIT, DDCIT, } \\
\text { SER, DSER, and PAR }\end{array}$ & LLE & MS & $\begin{array}{l}\mathrm{LOQ}=2 \mathrm{ng} / \mathrm{mL} \text { for CIT and PAR, } \\
1 \mathrm{ng} / \mathrm{mL} \text { for } S E R, 0.5 \mathrm{ng} / \mathrm{mL} \text { for } \\
\text { DSER, DCIT, and DDCIT }\end{array}$ & {$[56]$} \\
\hline Urine & $\begin{array}{l}\text { FLV, FLX, SER, VLF, and } \\
\text { CIT }\end{array}$ & SPME & MS (ESI mode) & $\mathrm{LOD}<0.4 \mathrm{ng} / \mathrm{mL}$ & {$[57]$} \\
\hline Blood & $\begin{array}{l}\text { VLF, FLX, FLV, CIT, and } \\
\text { SER }\end{array}$ & LLE & MS (ESI in SIM mode) & $\begin{array}{l}\mathrm{LOD}=<10,25,25,<10,4 \mathrm{ng} / \mathrm{mL} \text {, } \\
\text { and } \mathrm{LOQ}=25,50,25,25,50,25 \text {, } \\
20 \mathrm{ng} / \mathrm{mL} \text { for VLF, FLV, LX, CIT, } \\
\text { and SER, respectively }\end{array}$ & {$[58]$} \\
\hline $\begin{array}{l}\text { Oral } \\
\text { fluid }\end{array}$ & SER & SPE & MS in SIM mode. & $\mathrm{LOD}=18.6 \mathrm{ng} / \mathrm{mL}$ & {$[60]$} \\
\hline Plasma & $\begin{array}{l}\text { VLF, CIT, FLX, FLV, } \\
\text { SER, PAR, DFLX, DSER, } \\
\text { DCIT, and DDCIT }\end{array}$ & SPE & $\begin{array}{l}\text { Mass (ESI and Chemical } \\
\text { Ionisation }\left(\mathrm{PCI}^{*} / \mathrm{NCI}^{*}\right. \\
\text { source) in SIM mode) }\end{array}$ & $\begin{array}{l}\mathrm{LOQ}=5 \text { to } 12.5 \mathrm{ng} / \mathrm{mL} \text { in } \mathrm{ESI} \text { and } \\
\mathrm{PICI} \text { mode and } \mathrm{LOQ}=1 \text { to } \\
6.25 \mathrm{ng} / \mathrm{mL} \text { in NCI mode }\end{array}$ & [97] \\
\hline Plasma & CIT, DCIT, and DDCIT & LLE & MS & $\mathrm{LOQ}=1$ to $2 \mathrm{ng} / \mathrm{mL}$ & [98] \\
\hline \multicolumn{6}{|c|}{ Other detectors } \\
\hline Serum & CIT and DCIT & LLE & NPD & $\mathrm{LOQ}=10-20 \mathrm{mg} / \mathrm{L}$ & {$[63]$} \\
\hline Blood & CIT & SPE & NPD & $\mathrm{LOQ}=70 \mathrm{ng} / \mathrm{mL}$ & [99] \\
\hline Urine & $\begin{array}{l}\text { CIT, FLX, FLV, SER, and } \\
\text { PAR }\end{array}$ & SPE & FID & $\begin{array}{l}\text { LOQ }=91.7,64.9,100.3 \text {, and } 61.4 \text { and } \\
95.1 \mu \mathrm{g} / \mathrm{L} \text { for CIT, FLX, FLV, SER, } \\
\text { and PAR, respectively }\end{array}$ & {$[100]$} \\
\hline Plasma & $\begin{array}{l}\text { CIT, PAR, DLX, FLX, } \\
\text { and SER }\end{array}$ & In-tube SPME & UV & $\mathrm{LOQ}=50$ to $500 \mathrm{ng} / \mathrm{mL}$ & {$[101]$} \\
\hline
\end{tabular}

Abbreviations*: PCI: Positive Chemical Ionization, NCI: Negative Chemical Ionization.

forensic toxicological analysis that produced satisfactory results with different concentration ranges of analytes in small sample volume [58]. In general, the derivatizing agents mostly preferred during GC separation of antidepressant drugs were $\mathrm{N}$-methyl-N-trimethylsilyl-trifluoroacetamide for silylation, acetic anhydride-pyridine for acetylation, and trimethylammonium hydroxide for methylation [59].

The identification and quantification of psychoactive drugs like antidepressants can be obtained using alternative biological matrices like oral fluid. Analyses of SER and PAR were obtained with GC-MS(-MS), operating in SIM mode after their SPE from oral fluid. Due to the basic nature of these drugs, eluting solvent used in SPE is a mixture of dichloromethane: isopropanol: ammonium $(80: 20: 2, \mathrm{v} / \mathrm{v} / \mathrm{v})$. The chromatographic separation was performed on methylsilicone capillary column, and analytes were derivatized with $\mathrm{N}$ methyl-N-(trimethylsilyl)trifluoroacetamide and obtained retention time of 12.16 (SER) and $12.49 \mathrm{~min}$ (PAR). The method showed the applicability of alternative test matrices like oral fluid which have been extensively and successfully used to access acute and chronic exposure of drugs of abuse [60]. Similarly, in a suicidal case of multiple drug ingestion, CIT was identified and quantified in the postmortem samples by GC-MS. The concentrations of CIT found in femoral blood, heart blood, and urine were $0.88 \mathrm{mg} / \mathrm{L}, 1.16 \mathrm{mg} / \mathrm{L}$, and $0.9 \mathrm{mg} / \mathrm{L}$, respectively. This method also shows its applicability in the determination of CIT in postmortem tissue samples like liver, brain, gastric content, and so forth [61].

Moreover, full-scan EI ionization mode is also considered as the reference technique for drug screening procedures since it plays an important role in the analysis of drugs in forensic toxicology and doping control. The main advantage of this technique is that it provides comparable GC-MS spectra on all commercially available instruments since the standardized ionization EI mode produces unique and uniform mass fragmentation patterns. As a consequence, large mass spectral libraries have been constructed which enable the identification of unknown compounds [62]. Table 2 represents the GC methods that appeared in the literature for the determination of new generation antidepressant drugs and their metabolites.

2.2.2. Nitrogen Phosphorous Detector (NPD). Despite the differences in chemical structures of FLX, SER, CIT, VLF, DCIT, DSER, and NFLX, were successfully assayed in serum samples after LLE, followed by GC-NPD. It has been observed 
that for GC procedure, polarity of extracting solvent (proportion of isoamyl alcohol in the mixture with hexane) was one of the most important variables influencing extractions. An added factor, which was also considered during analysis, is the nitrogen containing structures of analytes and responsible for the high sensitivity obtained using nitrogen phosphorous detector (NPD) (helps in minimisation of interferences). The method was reported with good linearity $(20$ to $400 \mathrm{mg} / \mathrm{L})$ and correlation coefficients $(r=0.998)$. The specificity of the method can help during the toxicological screening of antidepressant drugs [63]. Even stereoselective determination of FLX and NFLX enantiomers were obtained by using the two-dimensional capillary gas liquid chromatography with NPD that allows the separation of racemic mixtures of the drugs in plasma or serum. A three-step LLE was used for sample preparation and provided linear calibration between 5-250 $\mathrm{ng} / \mathrm{mL}$ for (R)- and (S)-FLX and $15-250 \mathrm{ng} / \mathrm{mL}$ for (R)- and (S)-NFLX, with LOD $=1.5 \mathrm{ng} / \mathrm{mL}$ and $6 \mathrm{ng} / \mathrm{mL}$, respectively [64].

A comparative study was done for two types of extraction procedures regarding their recovery, precision, sensitivity, matrix purification efficiency, and less solvent consumption for the detection of SER and VLF in blood samples using GCNPD. First procedure consists of the employment of chem elut column (diatomaceous earth) based on the principle of solid-liquid absorption extraction and closely related to conventional LLE, while in the second bond, elut certify column was used with mixed SPE having reversed-phase and cation-exchange sorbents. Recoveries of the compounds using chem elut columns at $500 \mathrm{ng} / \mathrm{mL}$ were in the range of $28-74 \%$ and with LOD and LOQ ranging from 39 to $153 \mathrm{ng} / \mathrm{mL}$ and from 128 to $504 \mathrm{ng} / \mathrm{mL}$, respectively, while recoveries of the compounds using bond elut certify columns at $500 \mathrm{ng} / \mathrm{mL}$ were in the range of $64-86 \%$ and with LODs and LOQs ranging from 21 to $100 \mathrm{ng} / \mathrm{mL}$ and from 70 to $330 \mathrm{ng} / \mathrm{mL}$, respectively. Thus, the results suggested that the use of reversed-phase and cation-exchange sorbent bond elut certify columns is more satisfactory for the screening of the selected drugs [65]. In a similar kind of study, the use of mixed-mode bonded-silica bond elut certify columns had shown advantages rather than chem elut columns, in terms of recoveries, cleaner extracts, sensitivity, precision and solvent consumption. It has also been explained that the chem elut column has diatomaceous earth support which was a hydrophilic packing porous material acted as a support for the aqueous phase. Its high surface area ensured that the organic eluents remain immiscible with the aqueous matrix, eliminating emulsion problems and facilitating an efficient interaction between sample and organic solvents, while bond elut certify column was a mixed-mode bonded silica extraction support containing hydrophobic chains and strong cation-exchange moieties. This gave the ability to retain acidic, neutral, basic, and amphoteric drugs on one column which is quite advantageous in the field of forensic toxicology [66]. Table 2 represents the GC methods in combination with various detectors that appeared in the literature for the determination of SSRIs and SNRIs and their metabolites.
2.3. Electrodriven Methods. These are efficient and reliable analytical methods applied for the determination of enantiomers. Enantioseparations by capillary electrophoresis (CE) are generally achieved by adding a chiral selector to the running buffer, which reduces the cost of analysis with respect to some techniques such as HPLC chiral column. Cyclodextrins (CDs) are among the most prevalent selectors used in chiral CE. CE is one of the advantageous techniques used for the determination of small molecules in biological fluids which provides higher separation efficiency and selectivity in low sampling and solvent consumption. However, when biological fluids are injected directly into the capillary of CE unit, problems such as clogging of the capillary by particulate matter, irreversible binding of proteins, and peak distortion can occur because of the high salt concentration. Therefore, proper sample preparation or extraction is a must before analysis. The separation of SER, FLX, and FLV was described by CE with fully integrated SPE procedure. The SPE module was placed directly at the inlet of the capillary, and a mixture of all the analytes is extracted from aqueous solution by applying a simple pressure rinse. Under pressure-driven conditions, efficient elution was observed by using $50 \mathrm{mM}$ phosphate buffer $(\mathrm{pH}=3.5)$ in acetonitrile $(20 / 80, \mathrm{v} / \mathrm{v})$. It was observed that neutral monolith material in SPE gave an unstable electroosmotic flow, resulting in poor separation and elution. On the other hand, the addition of ionisable monomer (3-sulfopropyl methacrylate) to the SPE module has given improved and stable electroosmotic flow. This demonstrates the potential of inline SPE-CE for sensitive analysis of these drugs [67].

CE, combined with LPME (porous polypropylene hollow fibres), was evaluated for chiral determination of CIT in plasma. The CIT enantiomers (R- and S-CIT) were extracted from $0.5 \mathrm{~mL}$ of plasma in alkaline medium $(0.25 \mathrm{~mL}$ of $2 \mathrm{M}$ $\mathrm{NaOH})$. The unionised analytes were extracted into di-nhexyl ether, impregnated in the pores of the hollow fibre, and into an acidic solution inside the hollow fibre and obtained excellent recoveries for both enantiomers (80\%). This resulted in a three-phase system where the extracts were aqueous and hence directly compatible with the CE system. LOQ and LOD were found as $11.2 \mathrm{ng} / \mathrm{mL}$ and $3 \mathrm{ng} / \mathrm{mL}$ for both enantiomers, respectively. It has also been observed that the technique LPME-CE was a promising combination for the analysis of racemic drugs present in low concentrations in biological matrices [68].

Similar kind of extraction procedure was also adopted in combination with $\mathrm{CE}$, for the determination of CIT and its main metabolite N-DCIT in human plasma. The samples were made strongly alkaline which support proper extraction of the basic drugs like CIT. The drug and its metabolite were extracted into hexyl ether, impregnated in the pores of polypropylene hollow fibre, and into $25 \mu \mathrm{L}$ of $20 \mathrm{mM}$ phosphate buffer ( $\mathrm{pH}$ 2.75) present inside the hollow fibre (acceptor phase). This acceptor phase reduces the possibility of the majority of endogenic substances to penetrate inside hexyl ether layer. The instrument was operated at $20 \mathrm{kV}$, generating a current level of approximately $85 \mathrm{~mA}$. LOQ and LOD for citalopram and N-desmethylcitalopram were found 
to be $16.5 \mathrm{ng} / \mathrm{mL}$ and $18 \mathrm{ng} / \mathrm{mL}$ and $5 \mathrm{ng} / \mathrm{mL}$ and $5.5 \mathrm{ng} / \mathrm{mL}$, respectively [69].

Aqueous and nonaqueous CE-MS in ESI mode were investigated for the separation of VLF and its metabolites. The separation of analytes at basic $\mathrm{pH}$ was found effective in resolving the drugs, but created considerable peak tailing. To overcome electrostatic interactions between analytes and silanol groups, experiments were carried out at acidic $\mathrm{pH}$ which lead to fine separation. Resolution was achieved in less than $3.5 \mathrm{~min}$ by the use of fused-silica capillary and a methanol-acetonitrile mixture $(20 / 80 \mathrm{v} / \mathrm{v})$ containing $25 \mathrm{mM}$ ammonium formate and $1 \mathrm{M}$ formic acid. It was also observed that the selectivity, efficiency, and separation time were greatly affected by the organic solvent composition. Nonaqueous CE was found as an appropriate alternative to resolve VLF and its metabolites simultaneously, as the electric current generated in nonaqueous medium was very low and allowed baseline resolution of VLF and its metabolites in 0.7 min only. However, the electric field was further increased by reducing the capillary length [70].

Micellar electrokinetic chromatography (MEKC) with DAD was employed for the determination of CIT, SER, PAR, VLF, MCP, FLX, and their metabolites in urine samples. Here, the separation occurs on the basis of hydrophobic interaction with surfactant micelles. Separation and determination were optimised on an uncoated fused-silica capillary. The migration buffer consisted of $20 \mathrm{mM}$ sodium borate at $\mathrm{pH} 8.5$ with $20 \mathrm{mM}$ sodium dodecyl sulphate and $15 \%$ isopropanol, at an operating voltage of $25 \mathrm{kV}$ and column temperature at $40^{\circ} \mathrm{C}$. Injection in the capillary was performed in hydrodynamic mode ( $0.5 \mathrm{psi}, 15 \mathrm{~s}$ ) and obtained migration time less than $11 \mathrm{~min}$. Samples $(1 \mathrm{~mL})$ were extracted with diethyl ether $(5 \mathrm{~mL})$ at $\mathrm{pH} 9.6$ and reconstituted in diluted migration buffer. LOD and LOQ were in ranges between 10 and $20 \mathrm{ng} / \mathrm{mL}$ and between 20 and $30 \mathrm{ng} / \mathrm{mL}$, respectively, for all the molecules. This method allowed the determination of some of these analytes in biological fluids (blood and urine) obtained from postmortem cases that suggest the applicability of MEKC in forensic toxicological testing [71].

Recently, citalopram and its main active metabolite were analysed in human urine samples through a new MEKC method. The samples were purified and enriched by means of an extraction-preconcentration step with a preconditioned $\mathrm{C}_{18}$ cartridge and by eluting the compounds with methanol. Best results were obtained by using $15 \mathrm{mM}$ borate buffer (pH 9.2), containing $20 \mathrm{mM}$ sodium dodecyl sulphate and $12 \%(\mathrm{v} / \mathrm{v}) 2$-propanol as the background electrolyte. The separation was performed through a fused silica capillary with the application of hydrodynamic injection (pressure $=3.45 \mathrm{kPa}$ ) and $30 \mathrm{kV}$ of separation voltage. Under these conditions, the migration times were observed in the range of 3.0 to $8.0 \mathrm{~min}$, and the LODs were observed between 12.5 and $25 \mathrm{ng} / \mathrm{mL}$, respectively [72].

Since these compounds were produced in ionic form they can also be separated from capillary isotachophoresis (CITP). This is a technique used to separate charged particles, by using a discontinuous electrical field to create sharp boundaries between the sample constituents, thus creating separation. Conductivity detection of SER, CIT, FLX, and FLV has been done using CITP technique. This shows that it is a simple and quick method for the determination of these drugs [73]. An online preconcentration method, cation-selective exhaustive injection, and sweeping micellar electrokinetic chromatography (CSEI-sweeping-MEKC), with DAD, have been developed for the analysis of SSRIs. Under the optimized separation parameters, the enrichment factors for these five compounds when using CSEI-sweeping-MEKC fell within the range from $5.7 \times 10^{4}$ to $1.2 \times 10^{5}$, achieved LODs for the five SSRIs in human plasma between from 0.35 to $1.5 \mathrm{ng} / \mathrm{mL}$ [74].

\section{Conclusion}

The general trend observed in recent years for analysis of new generation antidepressant drugs is mostly emphasising separation techniques like liquid and gas chromatography in combination with various detectors. In this, the utmost analysis of has been observed with liquid chromatography in combination with mass, UV and fluorescence detectors. Gas chromatography has also been successfully applied with mass and nitrogen phosphorous detectors but required derivatisation of the concern drugs before analysis. This undeniably permits simultaneous analysis with high sensitivity and specificity and seemed to be suitable for their application in clinical and forensic studies. Moreover, in recent years, electrodriven techniques have been also becoming a viable alternative mean for analysis, providing high efficiency and short analysis time. In addition, for sample preparation, solventless microextraction techniques are evolved with tremendous possibilities and offer high sensitivity, accuracy, and enough reproducibility. However, despite of these advancements, efforts have still remained to focus on some alternative means of analysis which allow easier comparison and improved interpretation of results. Other chromatographic techniques like super critical fluid chromatography and ultra performance liquid chromatography would have become new analytical strategies especially for clinical and toxicological examinations and investigations of new generation antidepressant drugs.

\section{References}

[1] W. Z. Potter and L. E. Hollister, "Antidepressant Agents," in Lange: Basic and Clinical Pharmacology-Antidepressant Agent, B. G. Katzung, Ed., pp. 475-480, McGraw-Hill, New York, NY, USA, 2007.

[2] D. L. Musselman, D. L. Evans, and C. B. Nemeroff, "The relationship of depression to cardiovascular disease: epidemiology, biology, and treatment," Archives of General Psychiatry, vol. 55, no. 7, pp. 580-592, 1998.

[3] L. Romero, A. Montero, B. Fernandez, and J. M. Vela, "Depressive disorders: introductory and basic aspects," in Antidepressants, Antipsychotics, Anxiolytics-From Chemistry and Pharmacology to Clinical Application, H. Bushmann, J. Z. Diaz, J. Holenz, A. Parraga, A. Torrens, and J. M. Vela, Eds., pp. 3-35, Wiley-VCH, Weinheim, Germany, 2007.

[4] L. Iversen and R. D. Glennon, "Antidepressants," in Burger: Medicinal Chemistry and Drug Discovery of Nervous System 
Agents, D. J. Abraham, Ed., pp. 484-517, John Wiley \& Sons, New York, NY, USA, 2003.

[5] L. S. Goodman, G. J. Hardman, L. E. Limbird, and A. G. Gilman, Goodman \& Gilman's the Pharmacological basis of therepeutics, McGraw-Hill, New York, NY, USA, 2001.

[6] D. Murdoch and D. McTavish, "Sertraline. A review of its pharmacodynamic and pharmacokinetic properties, and therapeutic potential in depression and obsessive-compulsive disorder," Drugs, vol. 44, no. 4, pp. 604-624, 1992.

[7] M. Bauer, B. U. Monz, A. L. Montejo et al., "Prescribing patterns of antidepressants in Europe: results from the Factors Influencing Depression Endpoints Research (FINDER) study," European Psychiatry, vol. 23, no. 1, pp. 66-73, 2008.

[8] H. P. Rang, M. M. Dale, J. M. Ritter, and J. M. Flower, Rang \& Dale's Pharmacology, Elsevier, Churchill Levingstone, New York, NY, USA, 2007.

[9] I. M. Anderson, "Selective serotonin reuptake inhibitors versus tricyclic antidepressants: a meta-analysis of efficacy and tolerability," Journal of Affective Disorders, vol. 58, no. 1, pp. 19-36, 2000.

[10] S. Markowitz and A. Cuellar, "Antidepressants and youth: healing or harmful?" Social Science and Medicine, vol. 64, no. 10, pp. 2138-2151, 2007.

[11] L. Y. Katz, A. L. Kozyrskyj, H. J. Prior, M. W. Enns, B. J. Cox, and J. Sareen, "Effect of regulatory warnings on antidepressant prescription rates, use of health services and outcomes among children, adolescents and young adults," Canadian Medical Association Journal, vol. 178, no. 8, pp. 1005-1011, 2008.

[12] J. N. Jureidini, C. J. Doecke, P. R. Mansfield, M. M. Haby, D. B. Menkes, and A. L. Tonkin, "Efficacy and safety of antidepressants for children and adolescents," British Medical Journal, vol. 328, no. 7444, pp. 879-883, 2004.

[13] S. M. R. Wille, E. A. de Letter, M. H. A. Piette, L. K. van Overschelde, C. H. van Peteghem, and W. E. Lambert, "Determination of antidepressants in human postmortem blood, brain tissue, and hair using gas chromatography-mass spectrometry," International Journal of Legal Medicine, vol. 123, no. 6, pp. 451458, 2009.

[14] W. D. Hall, A. Mant, P. B. Mitchell, V. A. Rendle, I. B. Hickie, and P. McManus, "Association between antidepressant prescribing and suicide in Australia, 1991-2000: trend analysis," British Medical Journal, vol. 326, no. 7397, pp. 1008-1011, 2003.

[15] G. Isacsson, "Suicide prevention-a medical breakthrough?" Acta Psychiatrica Scandinavica, vol. 102, no. 2, pp. 113-117, 2000.

[16] P. Adamowicz and M. Kała, "Simultaneous screening for and determination of 128 date-rape drugs in urine by gas chromatography-electron ionization-mass spectrometry," Forensic Science International, vol. 198, no. 1-3, pp. 39-45, 2010.

[17] R. F. Suckow, M. F. Z. Ming Fen Zhang, and T. B. Cooper, "Sensitive and selective liquid-chromatographic assay of fluoxetine and norfluoxetine in plasma with fluorescence detection after precolumn derivatization," Clinical Chemistry, vol. 38, no. 9, pp. 1756-1761, 1992.

[18] A. Esrafili, Y. Yamini, and S. Shariati, "Hollow fiber-based liquid phase microextraction combined with high-performance liquid chromatography for extraction and determination of some antidepressant drugs in biological fluids," Analytica Chimica Acta, vol. 604, no. 2, pp. 127-133, 2007.

[19] B. V. Reddy, K. V. N. S. Reddy, J. Sreeramulu, and G. V. Kanumula, "Simultaneous determination of olanzapine and fluoxetine by HPLC," Chromatographia, vol. 66, no. 1-2, pp. 111114, 2007.
[20] C. Coulter, M. Taruc, J. Tuyay, and C. Moore, "Antidepressant drugs in oral fluid using liquid chromatography-tandem mass spectrometry," Journal of Analytical Toxicology, vol. 34, no. 2, pp. 64-72, 2010.

[21] B. N. Patel, N. Sharma, M. Sanyal, and P. S. Shrivastav, "Analysis of second-generation antidepressant drug, sertraline and its active metabolite, $\mathrm{N}$-desmethyl sertraline in human plasma by a sensitive and selective liquid chromatography-tandem mass spectrometry method," Journal of Chromatography B, vol. 877, no. 3, pp. 221-229, 2009.

[22] R. Mandrioli, M. A. Saracino, S. Ferrari, D. Berardi, E. Kenndler, and M. A. Raggi, "HPLC analysis of the secondgeneration antidepressant sertraline and its main metabolite Ndesmethylsertraline in human plasma," Journal of Chromatography $B$, vol. 836, no. 1-2, pp. 116-119, 2006.

[23] K. E. Goeringer, I. M. McIntyre, and O. H. Drummer, "LC-MS analysis of serotonergic drugs," Journal of Analytical Toxicology, vol. 27, no. 1, pp. 30-35, 2003.

[24] M. Kollroser and C. Schober, "An on-line solid phase extraction-liquid chromatography-tandem mass spectrometry method for the analysis of citalopram, fluvoxamine, and paroxetine in human plasma," Chromatographia, vol. 57, no. 3-4, pp. 133-138, 2003.

[25] S. Djordjevic, I. Kovacevic, B. Miljkovic, J. Vuksanovic, and M. Pokrajac, "Liquid chromatographic-mass spectrometric method for the determination of fluoxetine and norfluoxetine in human plasma: application to clinical study," Farmaco, vol. 60, no. 4, pp. 345-349, 2005.

[26] C. Fernandes, P. Jiayu, P. Sandra, and F. M. Lanças, "Stir bar sorptive extraction-LC-MS for the analysis of fluoxetine in plasma," Chromatographia, vol. 64, no. 9-10, pp. 517-521, 2006.

[27] X. Chen, X. Duan, X. Dai, and D. Zhong, "Development and validation of a liquid chromatographic/tandem mass spectrometric method for the determination of sertraline in human plasma," Rapid Communications in Mass Spectrometry, vol. 20, no. 16, pp. 2483-2489, 2006.

[28] A. de Castro, M. D. M. R. Fernandez, M. Laloup et al.,"Highthroughput on-line solid-phase extraction-liquid chromatography-tandem mass spectrometry method for the simultaneous analysis of 14 antidepressants and their metabolites in plasma," Journal of Chromatography A, vol. 1160, no. 1-2, pp. 312, 2007.

[29] A. J. Santos-Neto, J. Bergquist, F. M. Lanças, and P. J. R. Sjöberg, "Simultaneous analysis of five antidepressant drugs using direct injection of biofluids in a capillary restricted-access medialiquid chromatography-tandem mass spectrometry system," Journal of Chromatography A, vol. 1189, no. 1-2, pp. 514-522, 2008.

[30] M.-M. Zheng, S.-T. Wang, W.-K. Hu, and Y.-Q. Feng, "Intube solid-phase microextraction based on hybrid silica monolith coupled to liquid chromatography-mass spectrometry for automated analysis of ten antidepressants in human urine and plasma," Journal of Chromatography A, vol. 1217, no. 48, pp. 7493-7501, 2010.

[31] H. Hattori, K. Ito, M. Iwai et al., "Rapid analysis of sertraline, fluvoxamine, and paroxetine in serum specimens by LC-MSMS using a new polymer column," Forensic Toxicology, vol. 25, no. 2, pp. 100-103, 2007.

[32] M. A. Raggi, V. Pucci, R. Mandrioli, C. Sabbioni, and S. Fanali, "Determination of recent antidepressant citalopram in human plasma by liquid chromatography-fluorescence detection," Chromatographia, vol. 57, no. 5-6, pp. 273-278, 2003. 
[33] G. Frison, D. Favretto, S. Vogliardi, C. Terranova, and S. D. Ferrara, "Quantification of citalopram or escitalopram and their demethylated metabolites in neonatal hair samples by liquid chromatography-tandem mass spectrometry," Therapeutic Drug Monitoring, vol. 30, no. 4, pp. 467-473, 2008.

[34] H. Zhu, J. Luo, G. Zheng, and J. Shentu, "Sensitive and specific liquid chromatography-tandem mass spectrometry method for assay of fluoxetine and its metabolite norfluoxetine in human plasma and application of method to pharmacokinetic analysis," Journal of Analytical Chemistry, vol. 64, no. 9, pp. 941-950, 2009.

[35] H. Kirchherr and W. N. Kühn-Velten, "Quantitative determination of forty-eight antidepressants and antipsychotics in human serum by HPLC tandem mass spectrometry: a multi-level, single-sample approach," Journal of Chromatography B, vol. 843, no. 1, pp. 100-113, 2006.

[36] M. K. K. Nielsen, S. S. Johansen, P. W. Dalsgaard, and K. Linnet, "Simultaneous screening and quantification of 52 common pharmaceuticals and drugs of abuse in hair using UPLC-TOFMS," Forensic Science International, vol. 196, no. 1-3, pp. 85-92, 2010.

[37] D. Favretto, S. Vogliardi, G. Stocchero, A. Nalesso, M. Tucci, and S. D. Ferrara, "High performance liquid chromatography-high resolution mass spectrometry and micropulverized extraction for the quantification of amphetamines, cocaine, opioids, benzodiazepines, antidepressants and hallucinogens in $2.5 \mathrm{mg}$ hair samples," Journal of Chromatography A, vol. 1218, no. 38, pp. 6583-6595, 2011.

[38] P. P. Rop, A. Viala, A. Durand, and T. Conquy, "Determination of citalopram, amitryptyline and clomipramine in plasma by reversed-phase high-performance liquid chromatography," Journal of Chromatography, vol. 338, no. 1, pp. 171-178, 1985.

[39] J. Macek, P. Ptáček, and J. Klíma, "Rapid determination of citalopram in human plasma by high-performance liquid chromatography," Journal of Chromatography B, vol. 755, no. 1-2, pp. 279-285, 2001.

[40] E. M. Koves, "Use of high-performance liquid chromatographydiode array detection in forensic toxicology," Journal of Chromatography A, vol. 692, no. 1-2, pp. 103-119, 1995.

[41] I. M. McIntyre, C. V. King, S. Skafidis, and O. H. Drummer, "Dual ultaviolet wavelength high-performance liquid chromatographic method for the forensic or clinical analysis of seventeen antidepressants and some selected metabolites," Journal of Chromatography, vol. 621, no. 2, pp. 215-223, 1993.

[42] C. Frahnert, M. L. Rao, and K. Grasmäder, "Analysis of eighteen antidepressants, four atypical antipsychotics and active metabolites in serum by liquid chromatography: a simple tool for therapeutic drug monitoring," Journal of Chromatography B, vol. 794, no. 1, pp. 35-47, 2003.

[43] A. L. Hostetter, Z. N. Stowe, M. Cox, and J. C. Ritchie, "A novel system for the determination of antidepressant concentrations in human breast milk," Therapeutic Drug Monitoring, vol. 26, no. 1, pp. 47-52, 2004.

[44] A. R. Chaves, G. Chiericato Júnior, and M. E. C. Queiroz, "Solidphase microextraction using poly(pyrrole) film and liquid chromatography with UV detection for analysis of antidepressants in plasma samples," Journal of Chromatography B, vol. 877, no. 7, pp. 587-593, 2009.

[45] C. Greiner, C. Hiemke, W. Bader, and E. Haen, "Determination of citalopram and escitalopram together with their active main metabolites desmethyl(es-)citalopram in human serum by column-switching high performance liquid chromatography
(HPLC) and spectrophotometric detection," Journal of Chromatography B, vol. 848, no. 2, pp. 391-394, 2007.

[46] A. Oztunc, A. Onal, and S. Erturk, "7,7,8,8-Tetracyanoquinodimethane as a new derivatization reagent for high-performance liquid chromatography and thin-layer chromatography: rapid screening of plasma for some antidepressants," Journal of Chromatography B, vol. 774, no. 2, pp. 149-155, 2002.

[47] K. F. Overo, "Preliminary studies of the kinetics of citalopram in man," European Journal of Clinical Pharmacology, vol. 14, no. 1, pp. 69-73, 1978.

[48] E. Matsui, M. Hoshino, A. Matsui, and A. Okahira, "Simultaneous determination of citalopram and its metabolites by highperformance liquid chromatography with column switching and fluorescence detection by direct plasma injection," Journal of Chromatography B, vol. 668, no. 2, pp. 299-307, 1995.

[49] N. Unceta, A. Ugarte, A. Sánchez, A. Gómez-Caballero, M. A. Goicolea, and R. J. Barrio, "Development of a stir bar sorptive extraction based HPLC-FLD method for the quantification of serotonin reuptake inhibitors in plasma, urine and brain tissue samples," Journal of Pharmaceutical and Biomedical Analysis, vol. 51, no. 1, pp. 178-185, 2010.

[50] E. Lacassie, J.-M. Gaulier, P. Marquet, J.-F. Rabatel, and G. Lachâtre, "Methods for the determination of seven selective serotonin reuptake inhibitors and three active metabolites in human serum using high-performance liquid chromatography and gas chromatography," Journal of Chromatography B, vol. 742, no. 2, pp. 229-238, 2000.

[51] Y. Higashi, H. Matsumura, and Y. Fujii, "Determination of fluvoxamine in rat plasma by HPLC with pre-column derivatization and fluorescence detection using 4-fluoro-7-nitro-2,1,3benzoxadiazole," Biomedical Chromatography, vol. 19, no. 10, pp. 771-776, 2005.

[52] G. Bahrami, B. Mohammadi, A. Farshchi, and G. Ghiasi, "Quantitative analysis of sertraline in human serum by LC with fluorescence detection after pre-column derivatization with 4chloro-7-nitrobenzofurazan," Chromatographia, vol. 70, no. 1-2, pp. 323-327, 2009.

[53] G. J. de Jong and J. Zeeman, "The potential of pre-columns to improve detection properties in high-performance liquid chromatography," Chromatographia, vol. 15, no. 7, pp. 453-458, 1982.

[54] R. H. Pullen and A. A. Fatmi, "Determination of fluvoxamine in human plasma by high-performance liquid chromatography with fluorescence detection," Journal of Chromatography, vol. 574, no. 1, pp. 101-107, 1992.

[55] J. J. B. Nevado, M. J. V. Llerena, C. G. Cabanillas, V. R. Robledo, and S. Buitrago, "Sensitive capillary GC-MS-SIM determination of selective serotonin reuptake inhibitors: reliability evaluation by validation and robustness study," Journal of Separation Science, vol. 29, no. 1, pp. 103-113, 2006.

[56] C. B. Eap, "Simultaneous determination of human plasma levels of citalopram, paroxetine, sertraline, and their metabolites by gas chromatography-mass spectrometry," Journal of Chromatographic Science, vol. 36, no. 7, pp. 365-371, 1998.

[57] C. Salgado-Petinal, J. P. Lamas, C. Garcia-Jares, M. Llompart, and R. Cela, "Rapid screening of selective serotonin re-uptake inhibitors in urine samples using solid-phase microextraction gas chromatography-mass spectrometry," Analytical and Bioanalytical Chemistry, vol. 382, no. 6, pp. 1351-1359, 2005.

[58] T. Gunnar, S. Mykkänen, K. Ariniemi, and P. Lillsunde, "Validated semiquantitative/quantitative screening of 51 drugs in 
whole blood as silylated derivatives by gas chromatographyselected ion monitoring mass spectrometry and gas chromatography electron capture detection," Journal of Chromatography B, vol. 806, no. 2, pp. 205-219, 2004.

[59] U. Staerk and W. R. Külpmann, "High-temperature solid-phase microextraction procedure for the detection of drugs by gas chromatography-mass spectrometry," Journal of Chromatography B, vol. 745, no. 2, pp. 399-411, 2000.

[60] M. Pujadas, S. Pichini, E. Civit, E. Santamariña, K. Perez, and R. de la Torre, "A simple and reliable procedure for the determination of psychoactive drugs in oral fluid by gas chromatographymass spectrometry," Journal of Pharmaceutical and Biomedical Analysis, vol. 44, no. 2, pp. 594-601, 2007.

[61] K. Fu, R. J. Konrad, R. W. Hardy, R. M. Brissie, and C. A. Robinson, "An unusual multiple drug intoxication case involving citalopram," Journal of Analytical Toxicology, vol. 24, no. 7, pp. 648-650, 2000.

[62] S. M. Song, P. Marriott, A. Kotsos, O. H. Drummer, and P. Wynne, "Comprehensive two-dimensional gas chromatography with time-of-flight mass spectrometry (GC x GC-TOFMS) for drug screening and confirmation," Forensic Science International, vol. 143, no. 2-3, pp. 87-101, 2004.

[63] E. Lacassie, J.-M. Gaulier, P. Marquet, J.-F. Rabatel, and G. Lachâtre, "Methods for the determination of seven selective serotonin reuptake inhibitors and three active metabolites in human serum using high-performance liquid chromatography and gas chromatography," Journal of Chromatography B, vol. 742, no. 2, pp. 229-238, 2000.

[64] S. Ulrich, "Direct stereoselective assay of fluoxetine and norfluoxetine enantiomers in human plasma or serum by two-dimensional gas-liquid chromatography with nitrogenphosphorus selective detection," Journal of Chromatography $B$, vol. 783, no. 2, pp. 481-490, 2003.

[65] M. A. Martínez, C. Sánchez de la Torre, and E. Almarza, "Simultaneous determination of viloxazine, venlafaxine, imipramine, desipramine, sertraline, and amoxapine in whole blood: comparison of two extraction/cleanup procedures for capillary gas chromatography with nitrogen-phosphorus detection," Journal of Analytical Toxicology, vol. 26, no. 5, pp. 296-302, 2002.

[66] C. Sánchez de la Torre, M. A. Martínez, and E. Almarza, "Determination of several psychiatric drugs in whole blood using capillary gas-liquid chromatography with nitrogen phosphorus detection: comparison of two solid phase extraction procedures," Forensic Science International, vol. 155, no. 2-3, pp. 193-204, 2005.

[67] D. Schaller, E. F. Hilder, and P. R. Haddad, "Separation of antidepressants by capillary electrophoresis with in-line solidphase extraction using a novel monolithic adsorbent," Analytica Chimica Acta, vol. 556, no. 1, pp. 104-111, 2006.

[68] S. Andersen, T. G. Halvorsen, S. Pedersen-Bjergaard, K. E. Rasmussen, L. Tanum, and H. Refsum, "Stereospecific determination of citalopram and desmethylcitalopram by capillary electrophoresis and liquid-phase microextraction," Journal of Pharmaceutical and Biomedical Analysis, vol. 33, no. 2, pp. 263273, 2003.

[69] T. G. Halvorsen, S. Pedersen-Bjergaard, and K. E. Rasmussen, "Liquid-phase microextraction and capillary electrophoresis of citalopram, an antidepressant drug," Journal of Chromatography A, vol. 909, no. 1, pp. 87-93, 2001.

[70] S. Cherkaoui, S. Rudaz, and J. L. Veuthey, "Nonaqueous capillary electrophoresis-mass spectrometry for separation of venlafaxine and its phase I metabolites," Electrophoresis, vol. 22, pp. 491-496, 2001.

[71] L. Labat, M. Deveaux, P. Dallet, and J. P. Dubost, "Separation of new antidepressants and their metabolites by micellar electrokinetic capillary chromatography," Journal of Chromatography B, vol. 773, no. 1, pp. 17-23, 2002.

[72] J. Rodríguez Flores, A. M. C. Salcedo, M. J. V. Llerena, and L. M. Fernández, "Micellar electrokinetic chromatographic method for the determination of letrozole, citalopram and their metabolites in human urine," Journal of Chromatography A, vol. 1185, no. 2, pp. 281-290, 2008.

[73] T. Buzinkaiova and J. Polonsky, "Determination of four selective serotonin reuptake inhibitors by capillary isotachophoresis," Electrophoresis, vol. 21, pp. 2839-2841, 2000.

[74] H.-L. Su and Y.-Z. Hsieh, "Using cation-selective exhaustive injection and sweeping micellar electrokinetic chromatography to determine selective serotonin reuptake inhibitors," Journal of Chromatography A, vol. 1209, no. 1-2, pp. 253-259, 2008.

[75] W. Liu, F. Wang, and H.-D. Li, "Simultaneous stereoselective analysis of venlafaxine and O-desmethylvenlafaxine enantiomers in human plasma by HPLC-ESI/MS using a vancomycin chiral column," Journal of Chromatography B, vol. 850, no. 1-2, pp. 183-189, 2007.

[76] D. S. Jain, M. Sanyal, G. Subbaiah, U. C. Pande, and P. Shrivastav, "Rapid and sensitive method for the determination of sertraline in human plasma using liquid chromatography-tandem mass spectrometry (LC-MS/MS)," Journal of Chromatography B, vol. 829, no. 1-2, pp. 69-74, 2005.

[77] A. de Castro, M. Concheiro, O. Quintela, A. Cruz, and M. López-Rivadulla, "LC-MS/MS method for the determination of nine antidepressants and some of their main metabolites in oral fluid and plasma. Study of correlation between venlafaxine concentrations in both matrices," Journal of Pharmaceutical and Biomedical Analysis, vol. 48, no. 1, pp. 183-193, 2008.

[78] R. Green, R. Houghton, J. Scarth, and C. Gregory, "Determination of fluoxetine and its major active metabolite norfluoxetine in human plasma by liquid chromatography-tandem mass spectrometry," Chromatographia, vol. 55, pp. S133-S136, 2002.

[79] S. Souverain, M. Mottaz, S. Cherkaoui, and J.-L. Veuthey, "Rapid analysis of fluoxetine and its metabolite in plasma by LC-MS with column-switching approach," Analytical and Bioanalytical Chemistry, vol. 377, no. 5, pp. 880-885, 2003.

[80] J. Bhatt, A. Jangid, G. Venkatesh, G. Subbaiah, and S. Singh, "Liquid chromatography-tandem mass spectrometry (LC-MSMS) method for simultaneous determination of venlafaxine and its active metabolite $\mathrm{O}$-desmethyl venlafaxine in human plasma," Journal of Chromatography B, vol. 829, no. 1-2, pp. 75$81,2005$.

[81] C. Pistos, I. Panderi, and J. Atta-Politou, "Liquid chromatography-positive ion electrospray mass spectrometry method for the quantification of citalopram in human plasma," Journal of Chromatography B, vol. 810, no. 2, pp. 235-244, 2004.

[82] T. Jiang, Z. X. Rong, L. Peng et al., "Simultaneous determination of citalopram and its metabolite in human plasma by LCMS/MS applied to pharmacokinetic study," Journal of Chromatography B, vol. 878, no. 5-6, pp. 615-619, 2010.

[83] T. Shinozuka, M. Terada, and E. Tanaka, "Solid-phase extraction and analysis of 20 antidepressant drugs in human plasma by LC/MS with SSI method," Forensic Science International, vol. 162, no. 1-3, pp. 108-112, 2006.

[84] F. C. W. Sutherland, D. Badenhorst, A. D. de Jager et al., "Sensitive liquid chromatographic-tandem mass spectrometric 
method for the determination of fluoxetine and its primary active metabolite norfluoxetine in human plasma," Journal of Chromatography A, vol. 914, no. 1-2, pp. 45-51, 2001.

[85] H. Juan, Z. Zhiling, and L. Huande, "Simultaneous determination of fluoxetine, citalopram, paroxetine, venlafaxine in plasma by high performance liquid chromatography-electrospray ionization mass spectrometry (HPLC-MS/ESI)," Journal of Chromatography B, vol. 820, no. 1, pp. 33-39, 2005.

[86] N. Castaing, K. Titier, M. Receveur-Daurel et al., "Quantification of eight new antidepressants and five of their active metabolites in whole blood by high-performance liquid chromatography-tandem mass spectrometry," Journal of Analytical Toxicology, vol. 31, no. 6, pp. 334-341, 2007.

[87] W. R. Malfará, C. Bertucci, M. E. Costa Queiroz et al., "Reliable HPLC method for therapeutic drug monitoring of frequently prescribed tricyclic and nontricyclic antidepressants," Journal of Pharmaceutical and Biomedical Analysis, vol. 44, no. 4, pp. 955962, 2007.

[88] V. F. Samanidou and P. V. Kourti, "Rapid HPLC method for the simultaneous monitoring of duloxetine, venlaflaxine, fluoxetine and paroxetine in biofluids," Bioanalysis, vol. 1, no. 5, pp. 905917, 2009.

[89] P. Molander, A. Thomassen, L. Kristoffersen, T. Greibrokk, and E. Lundanes, "Simultaneous determination of citalopram, fluoxetine, paroxetine and their metabolites in plasma by temperature-programmed packed capillary liquid chromatography with on-column focusing of large injection volumes," Journal of Chromatography B, vol. 766, no. 1, pp. 77-87, 2002.

[90] K. Titier, N. Castaing, E. Scotto-Gomez, F. Pehourcq, N. Moore, and M. Molimard, "High-performance liquid chromatographic method with diode array detection for identification and quantification of the eight new antidepressants and five of their active metabolites in plasma after overdose," Therapeutic Drug Monitoring, vol. 25, no. 5, pp. 581-587, 2003.

[91] Z. Zheng, M. Jamour, and U. Klotz, "Stereoselective HPLCassay for citalopram and its metabolites," Therapeutic Drug Monitoring, vol. 22, no. 2, pp. 219-224, 2000.

[92] L. Kristoffersen, A. Bugge, E. Lundanes, and L. Slørdal, "Simultaneous determination of citalopram, fluoxetine, paroxetine and their metabolites in plasma and whole blood by highperformance liquid chromatography with ultraviolet and fluorescence detection," Journal of Chromatography B, vol. 734, no. 2, pp. 229-246, 1999.

[93] R. Waschgler, M. R. Hubmann, A. Conca, W. Moll, and P. König, "Simultaneous quantification of citalopram, clozapine, fluoxetine, norfluoxetine, maprotiline, desmethylmaprotiline and trazodone in human serum by HPLC analysis," International Journal of Clinical Pharmacology and Therapeutics, vol. 40, no. 12, pp. 554-559, 2002.

[94] B. Carlsson and B. Norlander, "Solid-phase extraction with endcapped C2 columns for the routine measurement of racemic citalopram and metabolites in plasma by high- performance liquid chromatography," Journal of Chromatography B, vol. 702, no. 1-2, pp. 234-239, 1997.

[95] C. Duverneuil, G. L. de la Grandmaison, P. de Mazancourt, and J.-C. Alvarez, "A high-performance liquid chromatography method with photodiode-array UV detection for therapeutic drug monitoring of the nontricyclic antidepressant drugs," Therapeutic Drug Monitoring, vol. 25, no. 5, pp. 565-573, 2003.

[96] N. Unceta, A. Gómez-Caballero, A. Sánchez et al., "Simultaneous determination of citalopram, fluoxetine and their main metabolites in human urine samples by solid-phase microextraction coupled with high-performance liquid chromatography," Journal of Pharmaceutical and Biomedical Analysis, vol. 46, no. 4, pp. 763-770, 2008.

[97] S. M. R. Wille, P. van Hee, H. M. Neels, C. H. van Peteghem, and W. E. Lambert, "Comparison of electron and chemical ionization modes by validation of a quantitative gas chromatographicmass spectrometric assay of new generation antidepressants and their active metabolites in plasma," Journal of Chromatography A, vol. 1176, no. 1-2, pp. 236-245, 2007.

[98] P. Reymond, M. Amey, A. Souche et al., "Determination of plasma levels of citalopram and its demethylated and deaminated metabolites by gas chromatography and gas chromatography-mass spectrometry," Journal of Chromatography, vol. 616, no. 2, pp. 221-228, 1993.

[99] M. A. Martínez, C. Sánchez de la Torre, and E. Almarza, "A comparative solid-Phase extraction study for the simultaneous determination of fluvoxamine, mianserin, doxepin, citalopram, paroxetine, and etoperidone in whole blood by capillary gasliquid chromatography with nitrogen-phosphorus detection," Journal of Analytical Toxicology, vol. 28, no. 3, pp. 174-180, 2004.

[100] J. J. Berzas, C. Guiberteau, M. J. Villaseñor, and V. Rodríguez, "Development of a capillary gas chromatographic procedure," Analytica Chimica Acta, vol. 519, no. 2, pp. 219-230, 2004.

[101] B. J. G. Silva, F. M. Lanças, and M. E. C. Queiroz, "In-tube solid-phase microextraction coupled to liquid chromatography (in-tube SPME/LC) analysis of nontricyclic antidepressants in human plasma," Journal of Chromatography B, vol. 862, no. 1-2, pp. 181-188, 2008. 

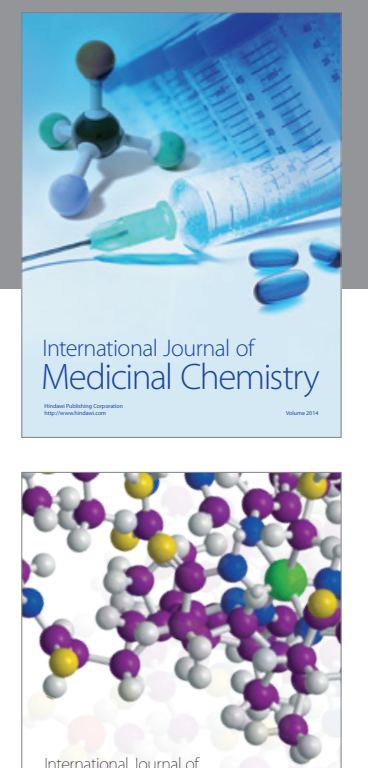

\section{Carbohydrate} Chemistry

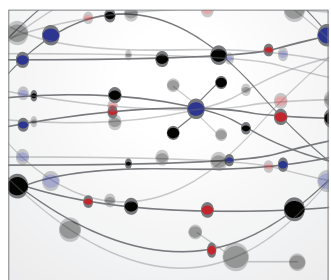

The Scientific World Journal
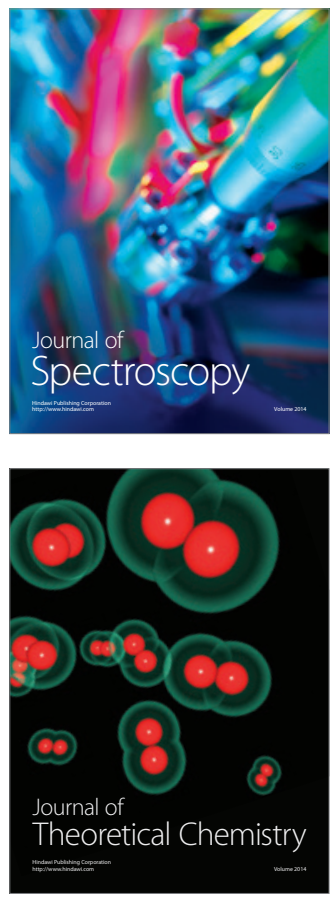
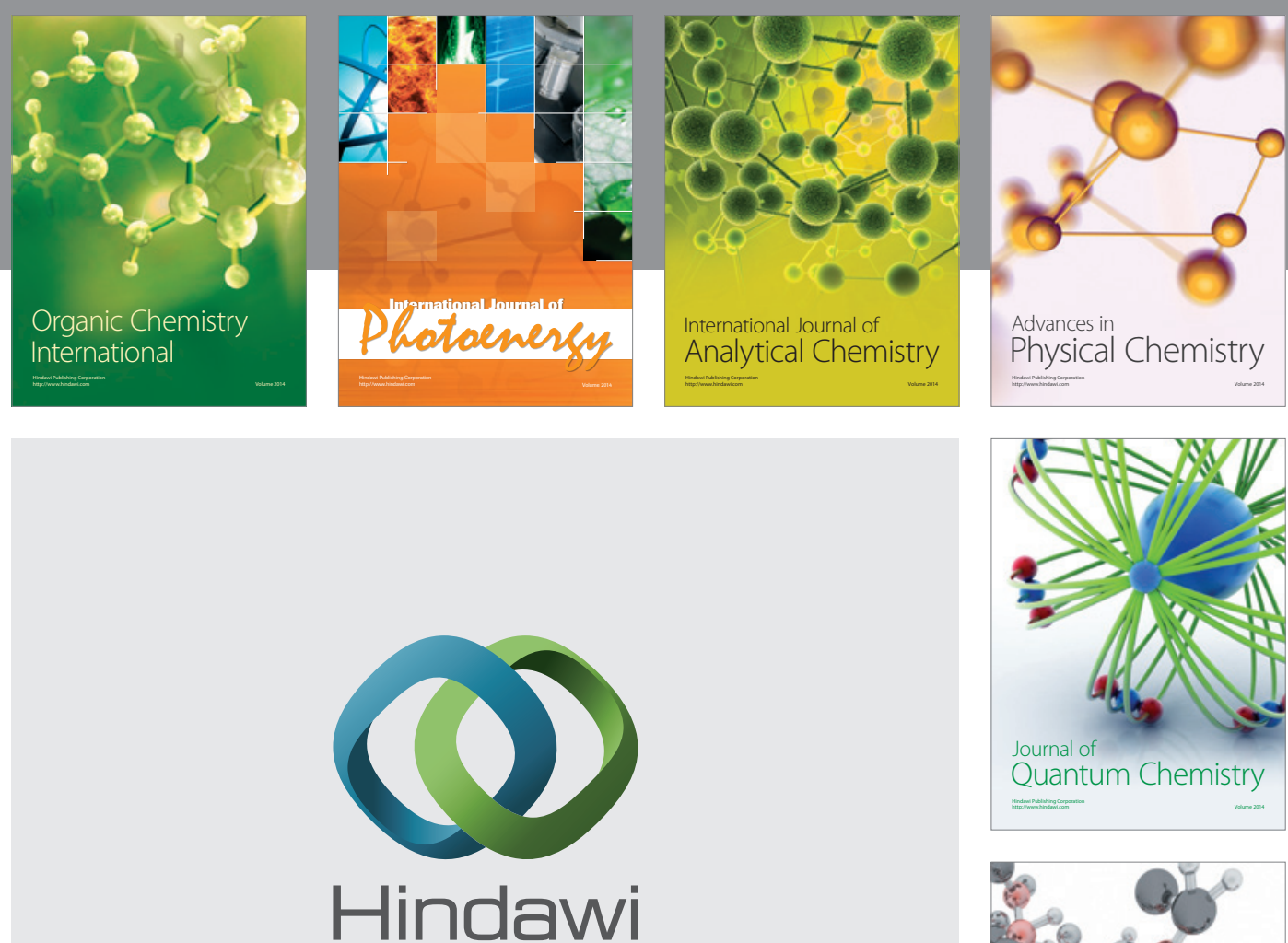

Submit your manuscripts at

http://www.hindawi.com

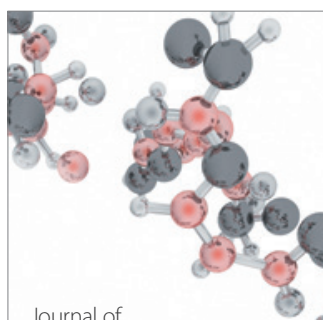

Analytical Methods

in Chemistry

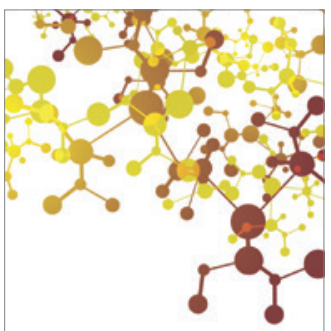

Journal of

Applied Chemistry

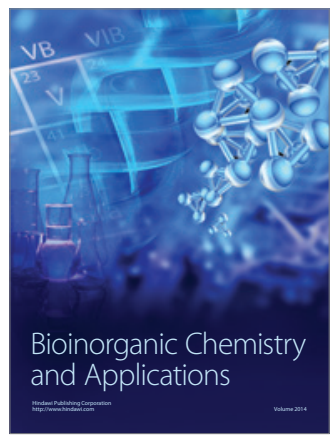

Inorganic Chemistry
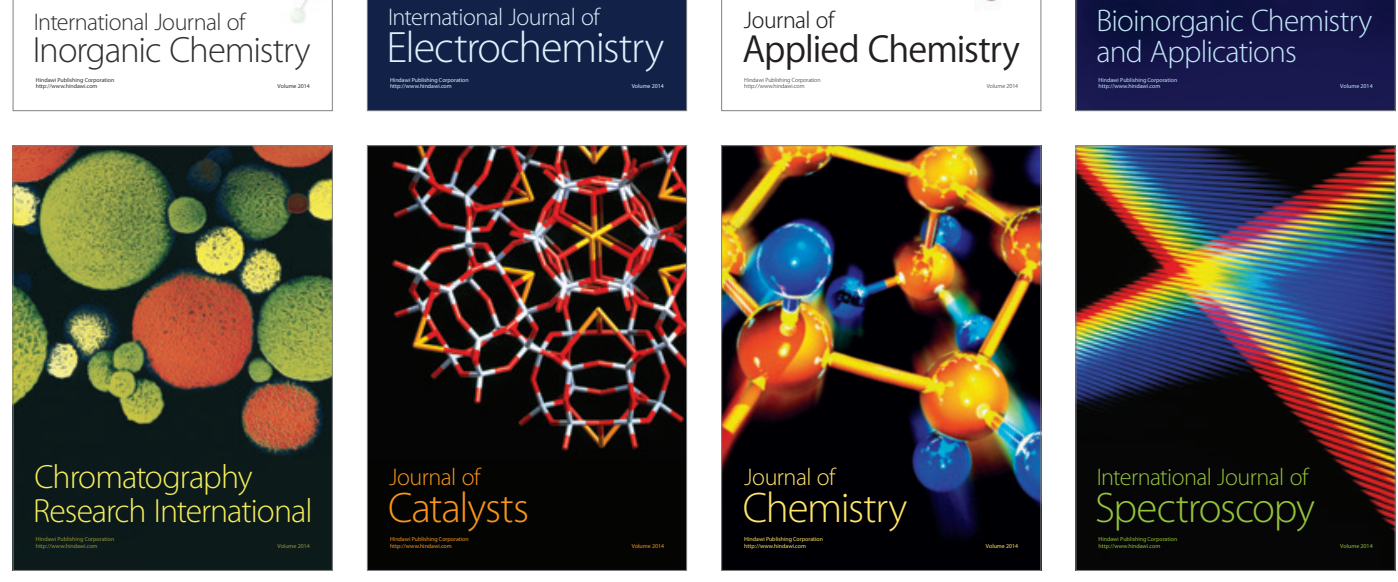